\title{
An Apolipoprotein E Synthetic Peptide Targets to Lipoproteins in Plasma and Mediates Both Cellular Lipoprotein Interactions In Vitro and Acute Clearance of Cholesterol-rich Lipoproteins In Vivo
}

Igor R. Nikoulin* and Linda K. Curtiss ${ }^{\star \ddagger}$

*Department of Immunology and ${ }^{\ddagger}$ Department of Vascular Biology, The Scripps Research Institute, La Jolla, CA 92037

\begin{abstract}
Apolipoprotein (apo) E mediates lipoprotein binding to cellular lipoprotein receptors. Previously we reported that a synthetic peptide representing a linear dimeric repeat of amino acids 141-155 binds cellular LDL receptors. To prepare an apoE peptide that bound to both cholesterol-rich lipoproteins and lipoprotein receptors, an $\mathrm{NH}_{2}$-terminal acetylated apoE dimer peptide was synthesized. This acetylated peptide preferentially associated with lipoproteins in plasma, whereas nonacylated peptides were poor lipid binders. Acetylated peptide/LDL complexes (molar ratios of 4-5:1) enhanced the interaction of LDL with cultured human fibroblasts by 7-12-fold. Participation by both receptors and cell surface heparin sulfate proteoglycans was observed. When a preformed peptide ${ }^{125} \mathrm{I}$-LDL complex was injected intravenously into $\mathrm{C} 57 \mathrm{BL} / 6 \mathrm{~J}$ apoE-deficient mice, its rate of removal was threefold higher than that of ${ }^{125} \mathrm{I}-\mathrm{LDL}$ alone. The liver and the spleen were major tissue distribution sites. Intravenous administration of free acetylated peptide resulted in a $30 \%$ reduction in total plasma cholesterol within 3-30 min, which reflected a $40-50 \%$ and $20-26 \%$ reduction in very low density lipoproteins and intermediate density lipoproteins, respectively. Therefore, this peptide selectively associated with cholesterol-rich lipoproteins and mediated their acute clearance in vivo. (J. Clin Invest. 1998. 101:223234.) Key words: apolipoprotein $\mathrm{E} \cdot$ cholesterol • peptides • receptors $\bullet$ proteoglycans
\end{abstract}

\section{Introduction}

Apolipoprotein (apo $)^{1} \mathrm{E}$ binds LDL receptors and participates in the transport of lipoprotein-associated cholesterol between

Address correspondence to Linda K. Curtiss, The Scripps Research Institute, Department of Immunology and Department of Vascular Biology, IMM-17, 10550 North Torrey Pines Road, La Jolla, CA 92037. Phone: 619-784-8248; FAX: 619-784-8480; E-mail: lcurtiss@ scripps.edu

Received for publication 2 July 1997 and accepted in revised form 3 November 1997.

1. Abbreviations used in this paper: Apo, apolipoprotein; BHT, butylated hydroxy toluene; HSPG, heparin sulfate proteoglycans; PC, phosphatidylcholine; PA, phosphatidic acid; LPDS, lipoproteindepleted fetal bovine serum; LRP, low density lipoprotein receptor related protein; RAP, receptor-associated protein.

J. Clin. Invest.

(C) The American Society for Clinical Investigation, Inc. 0021-9738/98/01/0223/12 \$2.00

Volume 101, Number 1, January 1998, 223-234

http://www.jci.org peripheral tissues and the liver (1). ApoE is found predominately in plasma in partially catabolized remnants of lipoproteins that carry either dietary cholesterol (chylomicrons) or liver-derived cholesterol (VLDL). A bolus injection of apoE reduces blood cholesterol in cholesterol-fed rabbits and Watanabe rabbits, and is rate-limiting for clearing cholesterol from the circulation (2-3). The importance of apoE in atherosclerosis has been established by molecular genetics. Mice overexpressing apoE have decreased levels of cholesterol (4). In contrast, mice with targeted gene mutations that result in the loss of apoE (5-7) have high levels of plasma cholesterol compared with wild-type mice (500 compared with 60-90 mg/ $\mathrm{dl}$ ), which is a result of impaired clearance of remnant lipoproteins that would normally be cleared by the liver because they contained apoE. These apoE-deficient mice also lose their normal resistance to cholesterol feeding. Serum cholesterol can rise to $>2,000 \mathrm{mg} / \mathrm{dl}$ on a high-fat, high-cholesterol diet, and the animals develop extensive atherosclerosis within months $(5,7)$. Bone marrow transplantation performed on hypercholesterolemic apoE-deficient mice with wild-type bone marrow cells expressing apoE reduces both serum cholesterol and severe atherosclerosis (8), and further establishes the importance of apoE for protection against atherosclerosis.

A region of apoE that binds the LDL receptor is localized to amino acid residues 140-160 (1). Because multiple molecules of apoE are required for high-affinity binding to the LDL receptor, we synthesized and tested the receptor-binding properties of a synthetic apoE peptide, which represents a dimeric tandem repeat of amino acid residues 141-155 (9). This synthetic dimeric peptide binds LDL receptors on cultured cells and blocks cellular binding of LDL. To define the structural requirements for the receptor-binding activity of this apoE dimer peptide, several modifications were made (10). At least two repeats of the 141-155 sequence are required for activity, because a longer peptide containing residues 129-163, but with only one copy of the 141-155 sequence, is inactive (911). The alpha-helical secondary structure of the dimeric repeat of residues $141-155$ is key because a leucine-to-proline substitution (Y[141-P-155]2) abolishes the alpha-helical structure and the receptor-binding activity (10). The distribution of the positively charged residues also are critical for activity (10). Unfortunately, this dimer peptide has weak lipid-binding properties (11). Our goal is to create an apoE synthetic peptide that will associate with cholesterol-rich lipoproteins in vivo, and ultimately target these lipoproteins to chylomicron remnant receptors $(12,13)$ and lipoprotein receptors in the liver. Cell surface heparin sulfate proteoglycans (HSPG) also bind apoE, and can participate in the liver association of the apoE-containing lipoproteins (14). Therefore, increased hepatic clearance of peptide-associated cholesterol-rich lipoproteins mediated by HSPG and lipoprotein receptors that result in lowered blood cholesterol could slow the progression and perhaps even promote regression of atherosclerotic lesions. 
Furthermore, because lesions most likely to precipitate myocardial infarction due to coronary thrombi are those where the lipid pool occupies $>15 \%$ of the vessel circumference (15), an increase in plasma apoE might also reduce the lipid content of those lesions that are at highest risk for rupture.

To influence plasma cholesterol metabolism in vivo, a receptor-active peptide must rapidly associate with cholesterol-rich lipoproteins in plasma. Therefore, we increased the hydrophobicity of the apoE dimer peptide by preparing two $\mathrm{NH}_{2}$-terminal-acetylated peptides, a palmitic acid, and an acetic acid peptide. The solubility, lipid-binding properties, plasma stability, and cellular binding properties of these peptides were studied. Moreover, the clearance rate and tissue distribution of peptide/lipoprotein complexes and their cholesterol-lowering properties were examined after their intravenous administration to apoE-deficient mice.

\section{Methods}

Computer modeling. The HyperChem III computer program (Autodesk Inc., Sausalito, CA) was used to predict the influence of modifications on peptide structure in solution. These structures were built using the AMBER force field. A first-order minimizer, a conjugate gradient method (Polak-Ribier version), was used for the energy minimization. The TIP3P water model (16) was used for solvation of peptide structure.

Peptide synthesis. All peptides were synthesized by the solidphase method of Merrifield on an Applied Biosystems model 430A automated peptide synthesizer (Foster City, CA) using hydroxybenzotrizol hydrate/dicyclohexylcarbodiimide activation as described (17). The resultant peptide resins were treated with $10 \%$ anisol/hydrogen fluoride at $24^{\circ} \mathrm{C}$ for $1 \mathrm{~h}$. Peptides $(10 \mu \mathrm{g}$ in $0.01 \mathrm{ml})$ were analyzed by HPLC using a reverse-phase Vydac C18 column $(4.6 \times 250 \mathrm{~mm})$ as described (Vydac/The Separations Group, Hesperia, CA; 11). Preparative purification of the peptides was obtained by chromatography on an Auto 500 preparative HPLC column $(50 \times 250-\mathrm{mm}$ reverse-phase Vydac C18 column, 15-20 $\mu \mathrm{m}$; Waters) using the same conditions (11). Amino acid compositions were determined using peptides hydrolyzed on a model 6300 high-performance analyzer operated with internal standard (Beckman Instruments, Fullerton, CA). Purity, as obtained from analytical HPLC chromatograms, and amino acid composition of all the peptides are listed in Table I.

The 16-carbon acyl chain of palmitic acid and 2-carbon acyl chain of acetic acid were covalently bound to the $\mathrm{NH}_{2}$-terminal tyrosine of $\mathrm{Y}(141-155)_{2}$ and $\mathrm{Y}(141-155)_{2} \mathrm{C}$, respectively (Table I). Acylation was achieved by reacting the fatty acid with the resin-bound peptide in the presence of dicyclohexylcarbodiimide and the catalyst, $N, N$-dimethylaminipyridine. After cleavage and deblocking of protecting groups, the acyl peptides were purified as described above.
All peptides were lyophilized and stored in a dark environment under vacuum. To prepare them for addition to cells or plasma, all peptides (except the palmitic acid peptide Pal-Y[141-155]2), were dissolved in PBS and dialyzed in Mr 1000 cutoff dialysis tubing (Spectrum Medical Industries, Inc., Houston, TX). The Pal-Y(141-155) peptide was dissolved in $100 \mathrm{mM}$ sodium cholate and introduced into liposomes as described below. Peptide concentrations were initially obtained from dry weight measurements and confirmed after solubilization with a modified (18) Lowry assay.

Lipoprotein isolation. Human plasma lipoproteins were isolated from fresh fasting plasma that was obtained by plasmapheresis from normal donors. LDL $(\mathrm{d}=1.019-1.063 \mathrm{~g} / \mathrm{ml})$ was isolated under strict sterile, endotoxin-free conditions by sequential ultracentrifugation using $\mathrm{KBr}$ for density adjustment as described (19). It was dialyzed against $0.15 \mathrm{mM} \mathrm{NaCl}$ containing $0.3 \mathrm{mM}$ EDTA and probucol, $\mathrm{pH}$ 7.4, filter-sterilized, and stored at $4^{\circ} \mathrm{C}$.

Radioiodination. ${ }^{125} \mathrm{I}$-Labeled LDL was prepared by the iodine monochloride procedure (20), and the final specific activities were $500-900 \mathrm{cpm} / \mathrm{ng}$. In every case, $>99 \%$ of the radioactivity was precipitable by incubation of the lipoproteins at $4^{\circ} \mathrm{C}$ with $10 \%(\mathrm{wt} / \mathrm{vol})$ trichloroacetic acid. The peptides were radioiodinated using the iodine monochloride method to a specific activity of $800-1,000 \mathrm{cpm} / \mathrm{ng}$. The Pal-Y(141-155) $)_{2}$ peptide was radioiodinated after dissolving it in $100 \mathrm{mM}$ sodium cholate. After dialysis, the precipitable radioactivity (10\% TCA) of the peptides was always $>97 \%$.

Pal-Y(141-155)2 liposomes. Liposomes were prepared by mixing phosphatidylcholine (PC, egg lecithin; Sigma Chemical Co., St. Louis, MO) and cholesterol at a molar ratio of 250:1. Cholesterol was added to a $13 \times 100-\mathrm{mm}$ glass tube and dried under nitrogen with the tube in a horizontal position. PC was added and dried in a similar manner without contacting the cholesterol. Then, the tube was placed upright, and peptides in $362.5 \mathrm{mM}$ sodium cholate in $10 \mathrm{mM}$ Tris- $\mathrm{HCl}$ buffer ( $\mathrm{pH} 7.2$ ) were added. The tube was covered with parafilm, vortexed for $60 \mathrm{~s}$, and the contents dialyzed in 12-14,000 molecular weight cutoff dialysis tubing overnight at $4^{\circ} \mathrm{C}$ against TRIS- $\mathrm{HCl}$ and 5 changes of PBS. Because Pal-Y(141-155) $)_{2}$ was not soluble at neutral $\mathrm{pH}$, it was introduced into the liposomes by dissolving it directly in $362.5 \mathrm{mM}$ sodium cholate and adding it to the dried PC. Furthermore, L- $\alpha$-phosphatidic acid (molar ratio of PC to phosphatidic acid of 1:1) increased the incorporation of Pal-Y(141-155) $)_{2}$ into the liposomes. Peptide content was determined with a modified (18) Lowry assay, total cholesterol was determined by the method of Gamble et al. (21), and phospholipids were determined by an enzymatic calorimetric method (Wako Pure Chemical Industries, Ltd., Osaka, Japan).

Plasma stability and distribution. The C57BL/6J apoE-deficient mice used for these studies were purchased from Jackson Labs (Bar Harbor, ME), and were bred in the Scripps vivarium. Animals were of both sexes, 2-4 mo old, and were chow-fed. Blood was drawn from nonfasted mice into heparin-coated tubes, and was subjected to lowspeed centrifugation $(1,200 \mathrm{~g})$ at $4^{\circ} \mathrm{C}$ to obtain the plasma that was stored at $-70^{\circ} \mathrm{C}$. To measure plasma stability, $1 \mathrm{nM}$ of radioiodinated

Table I. Characterization of the Synthetic ApoE Dimer Peptides

\begin{tabular}{|c|c|c|c|c|c|c|c|}
\hline \multirow[b]{2}{*}{ Peptide } & \multirow[b]{2}{*}{ Sequence } & \multirow[b]{2}{*}{ Residues } & \multirow[b]{2}{*}{ Purity* } & \multirow{2}{*}{$\begin{array}{c}\text { Solubility at } \\
\text { neutral pH }\end{array}$} & \multicolumn{2}{|c|}{ Binding } & \multirow{2}{*}{$\begin{array}{c}\text { Peptide/LDI } \\
\text { molar ratio }\end{array}$} \\
\hline & & & & & $\mathrm{LP}^{\ddagger}$ & LDL-R ${ }^{\S}$ & \\
\hline & & & $\%$ & & & & \\
\hline $\mathrm{Y}(141-155)_{2}$ & Y(LRKLRKRLLRDADDL $)_{2}$ & 31 & 93 & + & - & + & $<0.03$ \\
\hline $\mathrm{Y}(141-\mathrm{p}-155)_{2}$ & Y(LRKPRKRLLRDADDL $)_{2}$ & 31 & 95 & + & - & - & $<0.03$ \\
\hline Pal-Y $(141-155)_{2}$ & Pal-Y(LRKLRKRLLRDADDL $)_{2}$ & 31 & 95 & - & + & $\mathrm{ND}^{\mathrm{d}}$ & ND" \\
\hline $\mathrm{Ac}-\mathrm{Y}(141-155)_{2}$ & Ac-Y(LRKLRKRLLRDADDL $)_{2} \mathrm{C}$ & 32 & 91 & + & + & + & $4-5$ \\
\hline
\end{tabular}

*Percent purity as assessed by HPLC and amino acid composition analysis. ${ }^{*}$ Binding to lipoproteins. ${ }^{\S}$ Binding to the lipoprotein receptors on fibroblasts. ${ }^{\|}$Not determined due to insolubility of the peptide. 
peptide $(5-6 \mu \mathrm{g})$ was added to $0.25 \mathrm{ml}$ of plasma. After incubation at $37^{\circ} \mathrm{C}$, aliquots were removed and subjected to precipitation with $10 \%$ TCA. Because all peptides contained an $\mathrm{NH}_{2}$-terminal tyrosine, peptide degradation (i.e., TCA precipitability) reflected only the presence of an intact $\mathrm{NH}_{2}$-terminal tyrosine residue. To study the association of the apoE peptides with lipoproteins and/or other proteins in plasma, 15-20 $\mu \mathrm{g}(2.5-3.5 \mathrm{nmol})$ of radioiodinated peptide was incubated for $2 \mathrm{~h}$ at $37^{\circ} \mathrm{C}$ with $0.12 \mathrm{ml}$ of mouse plasma. The molar ratio of peptide/total lipoproteins was kept at 20:1 for $\mathrm{Y}(141-155)_{2}$ and $\mathrm{Y}(141-\mathrm{P}-155)_{2}$, and was 10:1 for Pal-Y(141-155) ${ }_{2}$ and Ac-Y(141$155)_{2}$ C. After incubation, plasma was chromatographed on a Superose 6 (HR 10/30) column (Pharmacia, Uppsala, Sweden; 8) in $10 \mathrm{mM}$ Tris- $\mathrm{HCl}, \mathrm{pH}$ 7.4, that contained $150 \mathrm{mM} \mathrm{NaCl}$ and $1 \mathrm{mM}$ EDTA. Fractions were collected and counted. The profile of the 10\% TCA precipitable radioactivity was compared with both the protein (absorbance at $280 \mathrm{nM}$ ) and cholesterol profiles. The plasmas were subjected to electrophoretic separation in 1\% agarose gel (Ciba Corning Diagnostics Corp., Norwood, MA) followed by staining with Fat Red 7B stain to reveal the lipoproteins, or exposure of the gel to autoradiographic film to reveal the radioiodinated peptides.

Peptide/LDL complexes. Peptide/lipoprotein complexes were formed by incubation of excess amounts of radiolabeled peptides for $2 \mathrm{~h}$ at $25^{\circ} \mathrm{C}$ with human plasma LDL diluted into PBS at a molar ratio of 25:1. The complexes were dialyzed to remove free peptide for 4-6 $\mathrm{h}$ at $4^{\circ} \mathrm{C}$ against PBS containing $20 \mu \mathrm{M}$ of butylated hydroxy toluene (BHT) and used immediately.

Fibroblast binding. Because we have previously used cultured human fibroblasts to study binding to lipoprotein receptors, they were used again in this study. Fibroblasts were cultured at $37^{\circ} \mathrm{C}$ in DMEM supplemented with $10 \%$ FBS, penicillin, and streptomycin (9). The cells were plated at $5 \times 10^{5}$ cells/ $/ \mathrm{ml}$ in 24 -well dishes in $1 \mathrm{ml}$ of medium, and were cultured for $2 \mathrm{~d}$. The day before the binding assays were performed, the medium was changed to DMEM containing $5 \%$ lipoprotein-depleted FBS to permit upregulation of LDL-receptors (20). Controls for LDL receptor binding were performed with fibroblasts cultured in DMEM containing 10\% FBS. The difference between total binding of ${ }^{125} \mathrm{I}$-ligands to up- and downregulated receptors was considered LDL receptor-specific. Cellular association was assayed after a 1-h incubation of the fibroblasts with the ligands in DMEM at $4^{\circ} \mathrm{C}$. The amount of ${ }^{125}$ I-labeled ligand bound in $1 \mathrm{~h}$ per culture well was normalized to the protein content of each well. Competition assays were carried out with cells that were incubated with an excess of unlabeled ligand. Ligand-specific binding was taken as the difference between total binding of the radiolabeled ligand and binding in the presence of an excess of unlabeled ligand.

The relative contribution of cell surface HSPG-to-lipoprotein binding was determined after heparinase treatment of the fibroblasts. The heparinase (Heparinase I, catalog no. H 2519; Sigma Chemical Co.) was dissolved at $3 \mathrm{U} / \mathrm{ml}$ in sterile $0.15 \mathrm{M} \mathrm{NaCl}$ and used immediately. Heparinase was added in tissue culture medium and incubated at $37^{\circ} \mathrm{C}$ for $2.5 \mathrm{~h}$ with human skin fibroblasts. After incubation, the cells were washed three times with medium to remove the enzyme. Heparinase activity and percent removal of cell surface proteoglycans were determined using a spectrophotometric assay $(22,23)$.

Tissue distribution of peptide/125 I-LDL complexes. ${ }^{125}$ I-LDL $(0.2$ nmol) was incubated at $37^{\circ} \mathrm{C}$ in PBS alone, or with $4 \mathrm{nmol}$ of the peptides shown in Table I. After $2 \mathrm{~h}$, the mixture was dialyzed against PBS containing $20 \mathrm{mM}$ of BHT (6-8 h with $4-5$ changes). ${ }^{125} \mathrm{I}-\mathrm{LDL}$ alone and each peptide ${ }^{125} \mathrm{I}$-LDL complex $(0.1 \mathrm{ml})$ were injected intravenously into the tail vein of nonfasted mice under metofane anesthesia. Mice were bled after the injection by retroorbital bleeding into heparinized tubes. The blood was subjected to low-speed centrifugation $\left(1800 \mathrm{~g}, 4^{\circ} \mathrm{C}\right)$ and the $10 \%$ TCA precipitable radioactivity of the plasma was measured. The mice were killed 8-9 min after injection, and blood was removed by perfusion with cold PBS via a cannula into the left ventricle. An incision was made in the inferior vena cava to clear the perfusate. Within 10-12 min, the liver, kidneys, spleen, and heart were removed, cleaned, weighed, and counted for ${ }^{125} \mathrm{I}$ radioac- tivity. Entire organs were counted with the exception of liver, which was counted in pieces. Radioactivity detected per organ or per $1 \mathrm{~g}$ of wet tissue was expressed as a percent of the initial total injected radioactivity that was TCA precipitable.

Effect of apoE peptides on plasma cholesterol. To monitor the influence of the peptides on total plasma cholesterol levels, the nonradioiodinated, free peptides including $\mathrm{Y}(141-155)_{2}(100 \mu \mathrm{g} / 15.4$ $\mathrm{nmol}), \mathrm{Y}(141-\mathrm{P}-155)_{2}(100 \mu \mathrm{g} / 15.8 \mathrm{nmol})$, and Ac-Y(141-155) ${ }_{2} \mathrm{C}(60$ $\mu \mathrm{g} / 7.1 \mathrm{nmol}$ ) were injected intravenously in $0.1 \mathrm{ml}$ of PBS into the tail vein of nonfasted mice. To control for the effect of external and/or internal nonspecific factors (stress, anaesthetic, and blood drawing) on plasma cholesterol levels, a similar group of chow-fed C57BL/6J apoE-deficient mice were injected with only PBS. Blood was drawn by retroorbital puncture from mice before and at various times after injection, and total plasma cholesterol was determined by the method of Gamble et al. (21).

In addition, plasmas $(0.1 \mathrm{ml})$ obtained at 15 min were subjected to gel filtration chromatography on a Superose 6 (HR 10/30 column; 8) to monitor lipoprotein distribution. The protein elution profile was monitored at $280 \mathrm{~nm}$, and the total cholesterol of individual fractions was measured as described by Gamble et al. (21).

\section{Results}

Peptides. The four peptides used in this study are listed in Table I. The dimer peptide, Y(141-155) 2 that corresponds to a direct repeat of amino acid residues $141-155$ of human apoE, is receptor-active (9-11). A tyrosine residue was added at the $\mathrm{NH}_{2}$ terminus of this peptide to allow for radioiodination, and this tyrosine does not interfere with its receptor-binding activity (9). Computer modeling of this peptide confirmed that it was amphipathic with opposing hydrophobic and hydrophilic faces that are rich in leucine or arginine and lysine residues, respectively. It had a distinct distribution of positively charged amino acid residues, $\alpha$-helical content, and a turn defined by residues arg-asp-ala. The proline-substituted dimer peptide $\mathrm{Y}(141-\mathrm{P}-155)_{2}$ was synthesized to generate a receptor-inactive control apoE peptide (10). The proline disrupted the $\alpha$-helix without altering charge. To improve the lipid-binding properties of the receptor-active dimer peptide, an $\mathrm{NH}_{2}$-terminal palmitic acid peptide was prepared (24-26). As outlined in detail below, this $\mathrm{NH}_{2}$-terminal palmitic acid had a major effect on peptide solubility. The fourth peptide was a dimer peptide with an $\mathrm{NH}_{2}$-terminal acetic acid, Ac-Y $(141-155)_{2} \mathrm{C}$. Because it was thought initially that the attachment of acetic acid at the $\mathrm{NH}_{2}$ terminus of this peptide would be insufficient to significantly increase its lipid-binding properties, a cysteine residue was included at the $\mathrm{COOH}$-terminal during its synthesis. This cysteine was added to allow for directional coupling in the future to other maleimide-activated $\mathrm{NH}_{2}$-terminal lipid-binding sequences (27). The computer-generated model of this fourth peptide indicated that it had a solvated structure closely resembling the receptor-active $\mathrm{Y}(141-155)_{2}$ peptide.

In vitro plasma stability. Upon addition to plasma drawn from apoE-deficient mice, $\sim 30 \%$ of the TCA precipitability of the ${ }^{125} \mathrm{I}-\mathrm{Y}(141-155)_{2}$ dimer peptide was lost in the first $2 \mathrm{~h}$ at $37^{\circ} \mathrm{C}$ (Fig. 1). Additional degradation (10-12\%) was observed during the subsequent $24 \mathrm{~h}$, and indicated that this peptide had relatively poor stability in plasma.

Because the Pal-Y(141-155) $)_{2}$ apoE dimer peptide was not soluble at neutral $\mathrm{pH}$, it could not be added directly to plasma. Therefore, it was solubilized by incorporating it into liposomes. Furthermore, because only $10-14 \mu \mathrm{g}$ of peptide was 


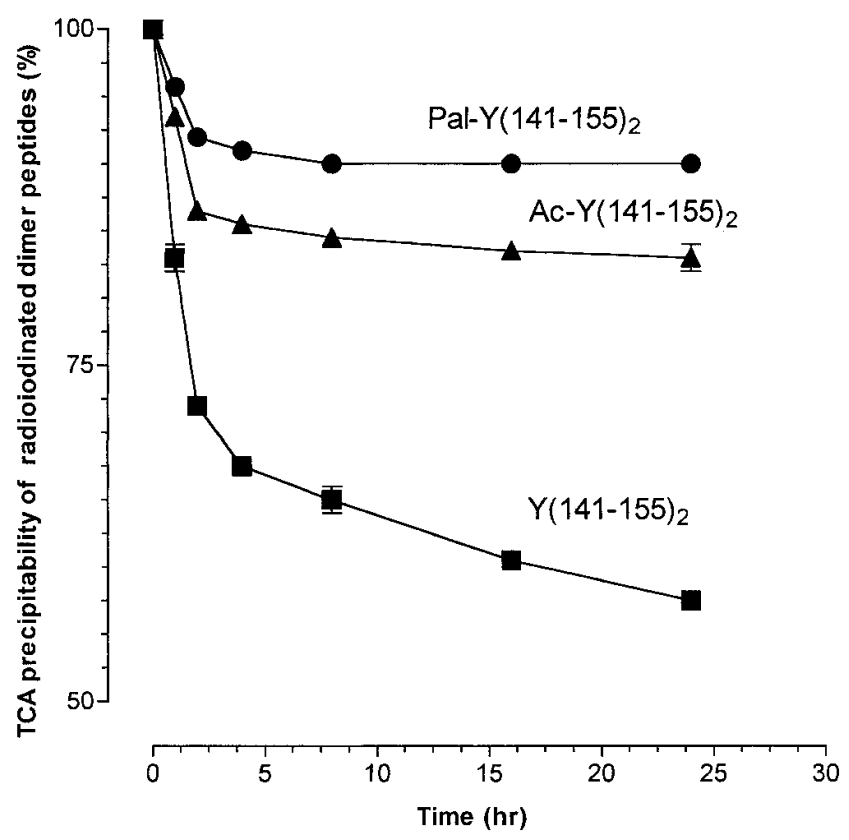

Figure 1. In vitro stability of apoE dimer peptides in apoE-deficient mouse plasma. Radioiodinated apoE dimer peptides are represented as follows: $\mathbf{\square}, \mathrm{Y}(141-155)_{2}(16 \mu \mathrm{g} / 2.46 \mathrm{nmol}) ; \bullet$, Pal-Y(141-155) $)_{2}$ in PC/PA liposomes $(16 \mu \mathrm{g} / 2.5 \mathrm{nmol})$; and $\boldsymbol{\Delta}$, Ac-Y $(141-155)_{2} \mathrm{C}(16 \mu \mathrm{g} /$ $1.9 \mathrm{nmol}$ ) were incubated with $0.2 \mathrm{ml}$ of plasma for $24 \mathrm{~h}$ at $37^{\circ} \mathrm{C}$. Aliquots were taken at times indicated, and TCA (10\%) precipitable radioactivity was determined. Degradation (\%) was expressed as percent of total amount of radioactivity added. Data is the mean \pm SD of three independent experiments. Note that the scale of TCA precipitability shown is between 100 and $50 \%$.

solubilized in $1 \mathrm{mg}$ of PC, phosphatidic acid (PA) was included to overcome the net positive charge of the peptide. At equal ratios of $\mathrm{PC}$ to $\mathrm{PA}$, the peptide content of the liposomes was $350-400 \mu \mathrm{g}$ of peptide per $\mathrm{mg}$ of total phospholipid. PC/PA liposomes containing 5-6 $\mu \mathrm{g}$ of ${ }^{125} \mathrm{I}-\mathrm{Pal}-\mathrm{Y}(141-155)_{2}$ peptide were added to plasma. In contrast to the ${ }^{125} \mathrm{I}-\mathrm{Y}(141-155)_{2}$ peptide, only $\sim 10 \%$ of the TCA precipitable radioactivity was lost in the first $5 \mathrm{~h}$ (Fig. 1). Minimal degradation of the peptide occurred during the subsequent $24 \mathrm{~h}$, and indicated that the ${ }^{125} \mathrm{I}-\mathrm{Pal}-\mathrm{Y}(141-155)_{2}$ peptide was considerably more resistant to $\mathrm{NH}_{2}$-terminal degradation in plasma.

The ${ }^{125} \mathrm{I}-\mathrm{AcY}(141-155)_{2} \mathrm{C}$ peptide was soluble at neutral $\mathrm{pH}$. When it was added to plasma, $\sim 15 \%$ of the peptide-associated radioactivity was lost in the first $2 \mathrm{~h}$ (Fig. 1), with minimal degradation occurring during the subsequent $24 \mathrm{~h}$. Therefore, this Ac- $\mathrm{Y}(141-155)_{2} \mathrm{C}$ peptide was more stable than the original dimer peptide, $\mathrm{Y}(141-155)_{2}$, but slightly less stable than the Pal-Y(141-155) 2 peptide. The increased stability of both $\mathrm{NH}_{2}$-terminal acylated peptides was probably a result of the protection of the $\mathrm{NH}_{2}$ terminal, which is in agreement with the influence of $\mathrm{NH}_{2}$-terminal residues on peptide stability (28).

Lipoprotein distribution chromatography. Chromatographic separation of plasma from chow-fed apoE-deficient mice verified that VLDL and IDL contained $\sim 85 \%$ of the total cholesterol, whereas LDL and HDL contained only 5 and $10 \%$ of the total cholesterol, respectively. Nevertheless, after $2 \mathrm{~h}$ at $37^{\circ} \mathrm{C}$, only $0.2,0.2,0.2$, and $0.4 \%$ of the total TCA precipitable radioactivity of the ${ }^{125} \mathrm{I}-\mathrm{Y}(141-155)_{2}$ peptide was recovered in VLDL, IDL, LDL, and HDL, respectively (data not shown). Among five plasmas studied, molar ratios of peptide per lipoprotein were consistently less than 1:25. Although the lipoprotein composition of individual plasmas varied somewhat (especially between males and females), the major cholesterol-carrying classes of lipoproteins were VLDL and IDL, the total cholesterol ratios of VLDL plus IDL to LDL plus HDL were the same, and the percentages of bound ${ }^{125} \mathrm{I}-\mathrm{Y}(141-155)_{2}$ were similarly low. This low molar ratio of peptide-to-lipoprotein indicated that this dimer peptide had a low affinity for lipoproteins.

The plasma lipoprotein distribution of ${ }^{125} \mathrm{I}-\mathrm{Pal}-\mathrm{Y}(141-155)_{2}$ was examined as well. PC/PA liposomes containing $4 \mathrm{nmol}$ of ${ }^{125} \mathrm{I}-\mathrm{Pal}-\mathrm{Y}(141-155)_{2}$ were incubated for $2 \mathrm{~h}$ at $37^{\circ} \mathrm{C}$ with $0.2 \mathrm{ml}$ of apoE-deficient plasma, and were chromatographed. Over $90 \%$ of the radiolabeled palmitic acid peptide was recovered in the lipoprotein fractions with $32,28,10$, and $18 \%$ of the total TCA-precipitable radioactivity recovered in VLDL, IDL, LDL, and HDL fractions, respectively (Fig. 2). The estimated average molar ratio of peptide/lipoprotein was about 8:1, and suggested good association of the palmitic acid peptide/liposomes with the lipoprotein fractions of plasma.

The in vitro distribution of ${ }^{125} \mathrm{I}-\mathrm{Ac}-\mathrm{Y}(141-155)_{2} \mathrm{C}$ among the plasma components of apoE-deficient mice was similar

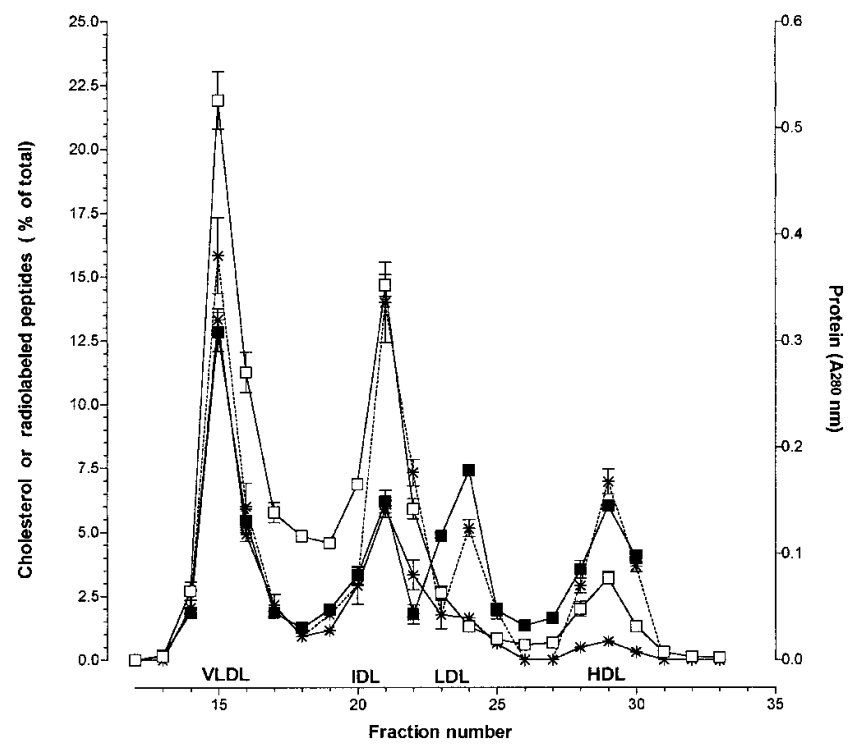

Figure 2. Chromatographic separation of apoE-deficient plasma to reveal the distribution of the ${ }^{125} \mathrm{I}-\mathrm{Pal}-\mathrm{Y}(141-155)$ and ${ }^{125} \mathrm{I}-\mathrm{Ac}-\mathrm{Y}(141-$ $155)_{2} \mathrm{C}$ synthetic peptides among lipoproteins. Radioiodinated apoE dimer peptides, Pal-Y(141-155) 2 (16 $\mu \mathrm{g}, 2.5 \mathrm{nmol})$ or Ac-Y $(141-$ $155)_{2} \mathrm{C}(16 \mu \mathrm{g}, 1.9 \mathrm{nmol})$, were incubated for $2 \mathrm{~h}$ at $37^{\circ} \mathrm{C}$ with $0.12 \mathrm{ml}$ of plasma in the presence of $10 \mu \mathrm{mol}$ BHT. $0.1 \mathrm{ml}$ of plasma was applied to a Superose 6 (HR 10/30 column), and 0.5-ml fractions were collected. Cholesterol $(\square)$, protein $(\square)$; ${ }^{125} \mathrm{I}-\mathrm{Pal}-\mathrm{Y}(141-155)_{2} \mathrm{C}$ radioactivity (*, hatched line) and ${ }^{125} \mathrm{I}-\mathrm{Ac}-\mathrm{Y}(141-155) \mathrm{C}$ radioactivity (*, solid line) was monitored. Radioactivity was expressed as percent of total TCA $(10 \%)$ precipitable radioactivity applied to the column. Cholesterol was expressed as percent of total cholesterol in $0.1 \mathrm{ml}$ of plasma. Results are the mean \pm SD of data obtained from five incubations. 
(Fig. 2). After the incubation of $16 \mu \mathrm{g}$ ( $2 \mathrm{nmol})$ of the ${ }^{125} \mathrm{I}-\mathrm{Ac}-\mathrm{Y}$ (141-155) $)_{2} \mathrm{C}$ peptide with $0.2 \mathrm{ml}$ of mouse plasma for $2 \mathrm{~h}$ at $37^{\circ} \mathrm{C},>30 \%$ of the TCA-precipitable radioactivity was recovered in fractions corresponding to the cholesterol-rich lipoproteins. Only $2 \%$ was recovered with HDL, suggesting that this peptide had good affinity for cholesterol-rich lipoproteins in plasma.

Lipoprotein distribution electrophoresis. Electrophoretic separation of apoE-deficient mouse plasma in a $1 \%$ agarose gel revealed that the major cholesterol-containing lipoprotein had prebeta mobility, whereas the LDL and HDL were weak and barely distinguishable (Fig. 3, lane 5). Similar mobilities were observed with plasmas incubated with either Y(141-155) or Y(141-P-155) $)_{2}$ (Fig. 3, lanes 2 and 3). Autoradiography of plasma samples containing radiolabeled ${ }^{125} \mathrm{I}-\mathrm{Y}(141-155)_{2}$ peptide identified a barely distinguishable radioactive band migrating with the prebeta VLDL, a weak diffuse band migrating with the HDL, and the major portion of the radioactivity remaining at the origin (data not shown). These results confirmed the absence of any remarkable peptide/lipoprotein interactions with either $\mathrm{Y}(141-155)_{2}$ or $\mathrm{Y}(141-\mathrm{P}-155)_{2}$.

Electrophoresis of plasma after incubation with nonradioiodinated Pal-Y(141-155) $)_{2}$ peptide in PC/PA liposomes revealed an increased mobility of the VLDL and IDL species (Fig. 3, lane 4). Moreover, incubation of this nonlabeled peptide with isolated human LDL revealed an increased mobility

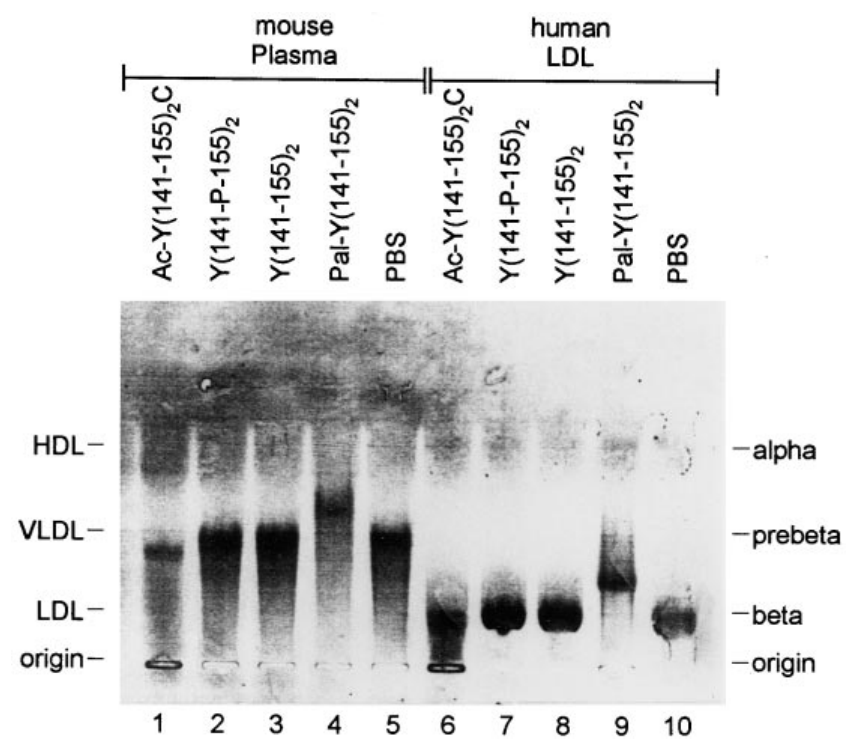

Figure 3. Effect of apoE synthetic peptides on the electrophoretic mobility of plasma lipoproteins of apoE-deficient mice and isolated human LDL. Plasma or human LDL $(0.1-0.12 \mathrm{nmol})$ were preincubated with apoE synthetic peptides $(1-2 \mathrm{nmol})$ at $25^{\circ} \mathrm{C}$ for $2 \mathrm{~h}$ in presence of $20 \mu \mathrm{M}$ of BHT and extensively dialyzed against PBS containing BHT. Each sample $(1 \mu \mathrm{l})$ was subjected to separation on a $1 \%$ agarose gel, stained with Fat Red 7B, and photographed. Plasma of apoE-deficient mice was preincubated with the following: lane 1,10.1 $\mathrm{nm}$ of Ac-Y(141-155) ${ }_{2} \mathrm{C}$; lane 2, $9.2 \mathrm{nmol}$ of $\mathrm{Y}(141-\mathrm{P}-155)_{2}$; lane 3, 8.2 nmol of Y(141-155) $)_{2}$; lane 4, PC/PA liposome containing $1.5 \mathrm{nmol}$ of Pal-Y(141-155 $)_{2}$; and lane 5, PBS. Isolated human LDL preincubated with the following: lane $6,1 \mathrm{nmol}$ of Ac-Y(141-155) ${ }_{2} \mathrm{C}$; lane 7, 4.2 nmol of $\mathrm{Y}(141-\mathrm{P}-155)_{2}$; lane 8, $3.2 \mathrm{nmol}$ of $\mathrm{Y}(141-155)_{2}$; lane 9, 1.5 $\mathrm{nmol}$ of Pal-Y(141-155) 2 ; and lane 10, PBS. The origin and migration distances are indicated.

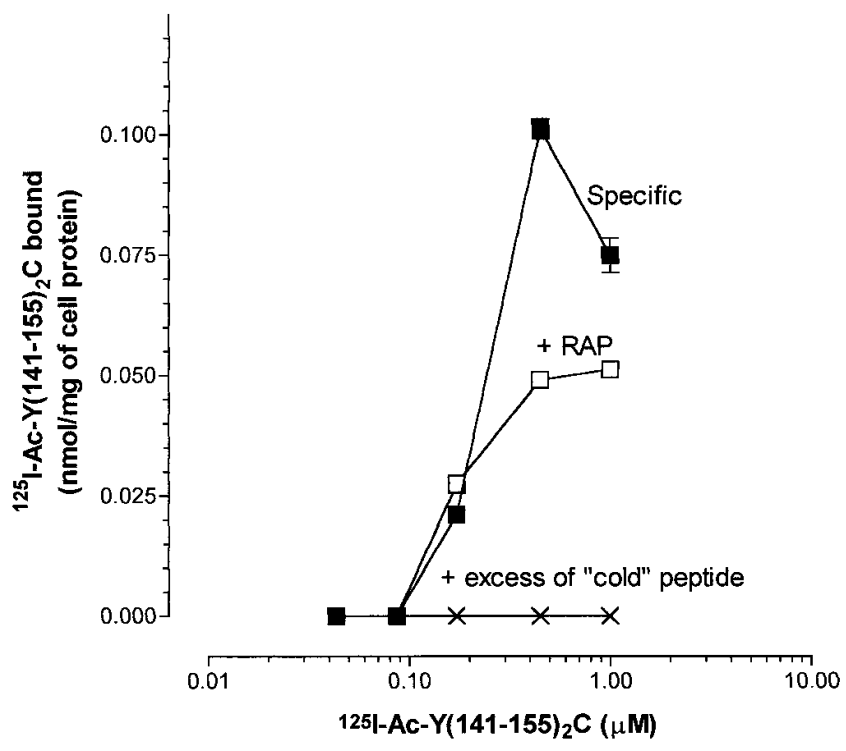

Figure 4. Binding of free ${ }^{125} \mathrm{I}-\mathrm{Ac}-\mathrm{Y}(141-155)_{2} \mathrm{C}$ peptide to human skin fibroblasts. Binding was conducted at $4^{\circ} \mathrm{C}$ for $1 \mathrm{~h}$ with ${ }^{125} \mathrm{I}-\mathrm{Ac}-\mathrm{Y}$ (141-155) ${ }_{2} \mathrm{C}$ at $0.04-1 \mu \mathrm{M}$. LDL receptor-specific binding (ם) was obtained by subtracting the binding to LDL receptor-downregulated cells from its binding to upregulated cells. RAP ( $\square)$, binding of peptide to LDL receptor-upregulated cells preincubated with $2 \mu \mathrm{M}$ of RAP for $1 \mathrm{~h}$ at $4^{\circ} \mathrm{C}$. Excess of cold peptide (X), binding of peptide to upregulated cells in the presence of a $25 \mathrm{nmol}$ excess of nonradiolabeled Ac-Y (141-155) ${ }_{2} \mathrm{C}$. Amount of ${ }^{125} \mathrm{I}-\mathrm{Ac}-\mathrm{Y}(141-155)_{2} \mathrm{C}$ bound was normalized per $1 \mathrm{mg}$ of cell protein. Each point represents the mean $\pm \mathrm{SD}$ of four replicates, and is representative of four experiments.

of the LDL (Fig. 3, lane 9) as well. This result strongly suggested that fusion of the liposomes with LDL had occurred. Incubation of the PC/PA liposomes containing ${ }^{125}$ I-Pal-Y(141$155)_{2}$ dimer peptide with human LDL followed by electrophoretic separation and autoradiography gave identical results (data not shown). Therefore, the attachment of a 16-carbon fatty acid to the $\mathrm{NH}_{2}$-terminal of the apoE dimer peptide dramatically increased its capacity to associate with lipoproteins. But, because this peptide was not soluble at neutral $\mathrm{pH}$ in the absence of phospholipid, its solubility (and therefore its usefulness) was severely compromised. Although this disadvantage could be overcome with the PC/PA liposomes, fusion of the highly charged peptide/liposome complexes with the lipoproteins appeared to be favored over peptide transfer from liposomes to lipoproteins.

Electrophoretic separation of the apoE-deficient mouse plasma preincubated with the Ac-Y(141-155) $)_{2} \mathrm{C}$ peptide resulted in decreased mobility of the prebeta lipoproteins (Fig. 3, lane 1). Electrophoretic separation of human LDL incubated with Ac-Y(141-155) $)_{2} \mathrm{C}$ followed by staining with Fat Red 7B stain resulted in a similar alteration of LDL mobility (Fig. 3, lane 6). These electrophoresis results were in agreement with the chromatography results, and suggested the stable formation in plasma of a complex between Ac-Y(141-155) $)_{2} \mathrm{C}$ and cholesterol-rich lipoproteins.

Cell association. Because the Ac-Y(141-155) $)_{2} \mathrm{C}$ peptide was soluble at neutral $\mathrm{pH}$ and could associate with lipoproteins, we explored the cellular binding properties of this peptide to cultured human skin fibroblasts. Initially, the ability of 
the lipid-free peptide to bind to lipoprotein receptors on fibroblasts was examined. When ${ }^{125} \mathrm{I}-\mathrm{Ac}-\mathrm{Y}(141-155)_{2} \mathrm{C}$ was incubated with fibroblasts, LDL receptor-specific binding (calculated by subtracting binding to LDL receptor-downregulated cells from binding to LDL receptor-upregulated cells) was maximal at a peptide concentration of $0.2 \mathrm{nmol} / \mathrm{mg}$ of cell protein (Fig. 4). This LDL receptor-specific binding was completely inhibited by a 25 -fold excess of nonradioiodinated Ac$\mathrm{Y}(141-155)_{2} \mathrm{C}$, and was partially inhibited by preexposure of the cells to $1 \mathrm{nmol}$ of the receptor-associated protein (RAP), a protein that can block both LDL and LRP-receptor interactions (29-30), but at the concentration used is more effective at inhibiting binding to LRP interactions. This result indicated that the ${ }^{125} \mathrm{I}-\mathrm{Ac}-\mathrm{Y}(141-155)_{2} \mathrm{C}$ dimer peptide bound to cells in a manner that was previously demonstrated for the ${ }^{125} \mathrm{I}-\mathrm{Y}(141-$ $155)_{2}$ peptide $(9,10)$.

To test whether this peptide enhanced the cellular association of apoE-free LDL, peptide/LDL complexes were prepared in vitro. With radioiodinated Ac-Y $(141-155)_{2} \mathrm{C}$, a stable peptide/LDL complex was observed at neutral $\mathrm{pH}$ after dialysis, which contained 4-5 molecules of peptide per LDL particle. Using these same conditions, we prepared complexes to examine the cell association of radioiodinated LDL. Binding of apoE-free ${ }^{125} \mathrm{I}$-LDL at $4^{\circ} \mathrm{C}$ to LDL receptor-upregulated fibroblasts was observed at LDL concentrations between 1 and 20 pmol per well (Fig. $5 A$ ), and this binding was reduced by either excess cold LDL (20-fold) or 1 nM RAP. More notably, this binding of ${ }^{125} \mathrm{I}-\mathrm{LDL}$ was substantially increased when the LDL was complexed first with 4-5 molecules of Ac-Y(141$155)_{2} \mathrm{C}$ (Fig. $\left.5 \mathrm{~B}\right)$. The total binding of LDL at a ligand concentration of $10 \mathrm{pmol} / \mathrm{well}$ was increased from 0.46 to $4.0 \mathrm{pmole} /$ $\mathrm{mg}$ of cell protein by the peptide. If the difference between binding to upregulated (total) versus downregulated fibroblasts is assumed to be LDL receptor-specific, the data of Fig. $5 \mathrm{~B}$ suggested that greater than half of the enhanced binding of the peptide/LDL complex was LDL receptor-specific. Smaller percentages were inhibited by RAP, or were bound to fibroblasts cultured in the presence of serum (downregulated). ${ }^{125} \mathrm{I}-$ LDL incubated with the original dimer peptide, Y(141-155), or with the $\mathrm{Y}(141-\mathrm{P}-155)_{2}$ dimer peptide at comparable peptide/LDL concentrations, did not enhance the association of ${ }^{125}$ I-LDL with cells (data not shown).

As illustrated in Fig. $5 \mathrm{~B}$, binding of the peptide ${ }^{125} \mathrm{I}-\mathrm{LDL}$ complex to LDL receptor-downregulated cells was observed. This result suggested that the peptide/lipoprotein complexes were interacting with other cellular sites, sites that were not downregulated by preincubation of the fibroblasts in lipoprotein-containing serum. Chylomicron remnants enriched in apoE exhibit enhanced binding to HepG2 cells and human skin fibroblasts, and this binding is reduced $80 \%$ by Heparinase treatment (14). Therefore, we investigated whether HSPG participated in the binding of peptide/LDL complexes. Fibroblasts pretreated with Heparinase I removed $45 \pm 10 \%$ of the total proteoglycans $(n=4)$, but did not reduce the binding of peptide-free ${ }^{125}$ I-LDL (Fig. 6). This result was in agreement with previous data for LDL and beta VLDL binding to cultured cells $(14,31-32)$. However, the enhanced binding of the Ac-Y(141-155) ${ }_{2} \mathrm{C} /{ }^{125}$ I-LDL complexes was blocked almost $70 \%$ by preincubation of the fibroblasts with Heparinase I (Fig. 6). This result suggested that HSPG on the surface of the fibroblasts participated in the enhanced binding of preformed peptide/LDL complexes.
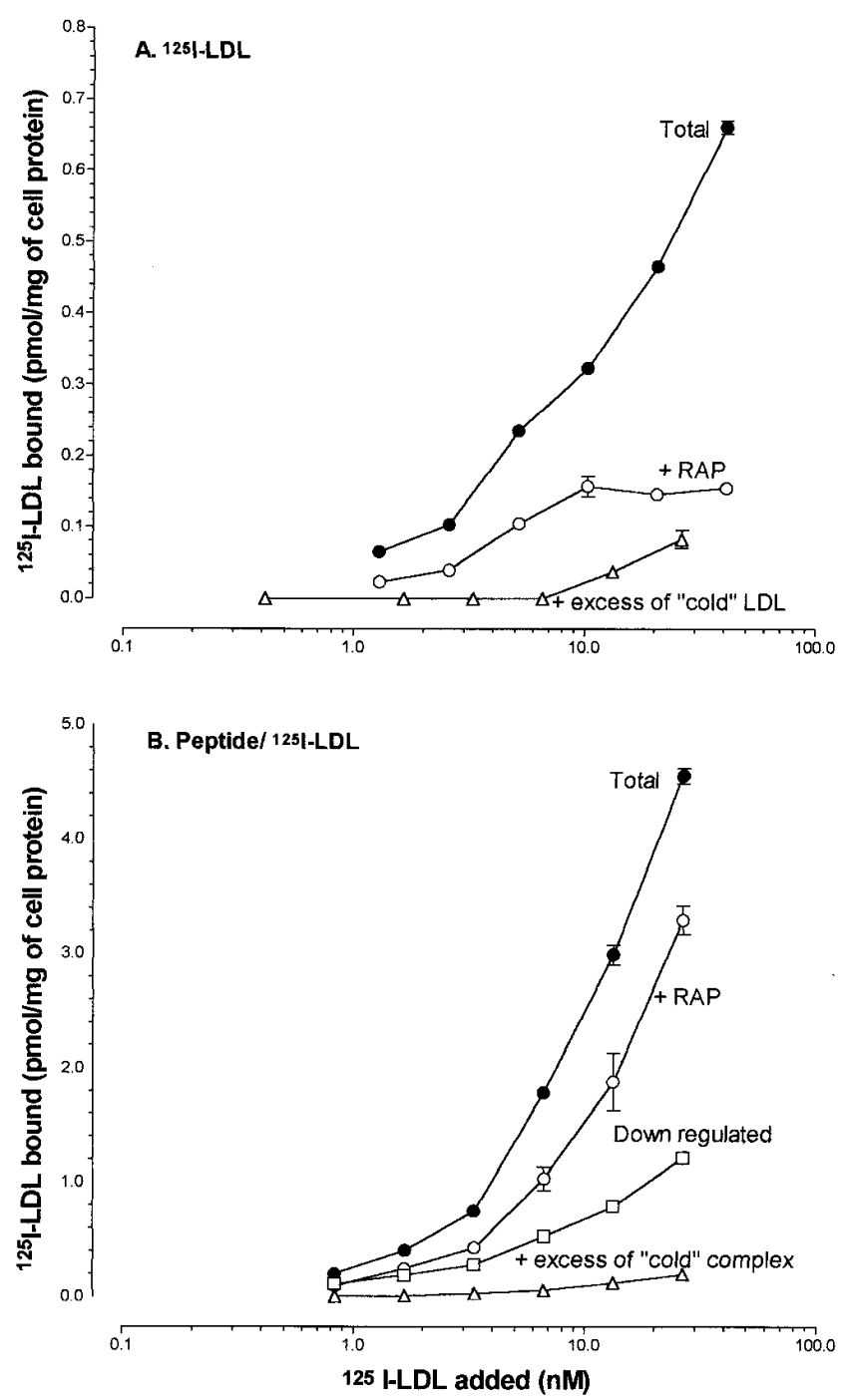

Figure 5. (A) Binding of ${ }^{125} \mathrm{I}-\mathrm{LDL}$ to human skin fibroblasts. Binding was conducted at $4^{\circ} \mathrm{C}$ for $1 \mathrm{~h}$ with ${ }^{125} \mathrm{I}-\mathrm{LDL}$ at $0.4-40 \mathrm{nM}$. $\bullet$, Total binding to LDL-R-upregulated fibroblasts; $\bigcirc$, binding after preexposure of the cells to $1-2 \mu \mathrm{M}$ of RAP for $1 \mathrm{~h}$ at $4^{\circ} \mathrm{C} ; \triangle$, binding to the fibroblasts in the presence of a 20 -fold excess of cold LDL . Each point represents the mean \pm SD of four replicates, and is representative of four experiments. $(B)$ Binding of peptide $/{ }^{125} \mathrm{I}-\mathrm{LDL}$ complexes to human skin fibroblasts. Binding was conducted at $4^{\circ} \mathrm{C}$ for $1 \mathrm{~h}$ with Ac$\mathrm{Y}(141-155)_{2} \mathrm{C} /{ }^{125} \mathrm{I}-\mathrm{LDL}$ at $0.8-30 \mathrm{nM}$. $\bullet$, Total binding to LDL$\mathrm{R}$-upregulated fibroblasts; $\bigcirc$, binding to cells preexposed to 1-2 $\mu \mathrm{M}$ of RAP for $1 \mathrm{~h}$ at $4^{\circ} \mathrm{C} ; \square$, binding to cells cultured in complete serum (LDL-R-downregulated cells ); $\triangle$, binding in the presence of a 20 fold excess of cold peptide/LDL complexes. Preincubation of ${ }^{125} \mathrm{I}$ LDL preparation with $\mathrm{Y}(141-155)_{2}$ or $\mathrm{Y}(141-\mathrm{P}-155)_{2}$ under the conditions required for complex formation did not enhance its binding to the cells (data not shown). Each point represents the mean \pm SD of four replicates, and is representative of five experiments.

Plasma clearance and tissue distribution of peptide/LDL complexes. Peptide/ ${ }^{125}$ I-LDL complexes were prepared in vitro, and were injected intravenously into apoE-deficient mice. To compare the rates of removal from plasma, the $10 \%$ TCA precipitable radioactivity of the radioiodinated LDL was monitored in the plasma of apoE-deficient mice 3,10, and 60 $\mathrm{min}$, and $24 \mathrm{~h}$ after injection. As expected, plasma clearance of 


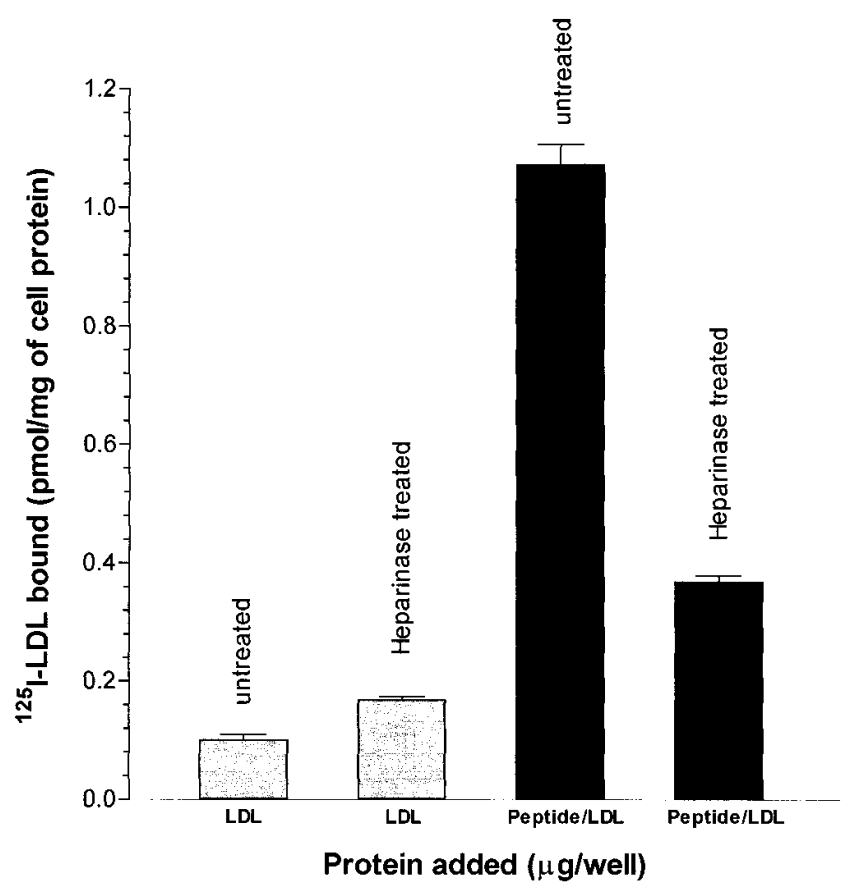

Figure 6. Effect of Heparinase I treatment of human skin fibroblasts on the ability of apoE peptides to enhance ${ }^{125} \mathrm{I}-\mathrm{LDL}$ binding. Cells were incubated in absence or presence of Heparinase I $(2.5 \mathrm{U} / \mathrm{ml}$, $\left.37^{\circ} \mathrm{C}, 2.5 \mathrm{~h}\right)$. Binding was conducted at $4^{\circ} \mathrm{C}$ for $1 \mathrm{~h} .{ }^{125} \mathrm{I}-\mathrm{LDL}$ and $\operatorname{AcY}(141-155)_{2} \mathrm{C} /{ }^{125} \mathrm{I}-\mathrm{LDL}$ (ratio of 4:1) were used at $4 \mu \mathrm{g}$ of LDL protein/well $(0.5 \mathrm{ml})$, which was equal to $4.6 \mathrm{pmol}$ of LDL/well. Amount of ${ }^{125} \mathrm{I}$-LDL bound to the cells was normalized to $1 \mathrm{mg}$ of cell protein. Each point represents the mean \pm SD of four replicates.

${ }^{125}$ I-LDL and control peptide/ $/ 25$ I-LDL complexes, which, as shown in Table I had peptide/LDL molar ratios of $<0.03$, were similar with approximately half of the injected dose remaining at $30 \mathrm{~min}$ (Fig. 7). This result was in sharp contrast to the clearance of the Ac-Y $(141-155)_{2} \mathrm{C}^{125} \mathrm{I}-\mathrm{LDL}$ complexes, which were cleared more rapidly. Within 3 min of injection, $50 \%$ of the Ac-Y(141-155) 2 C/LDL complex, which contained $4-5$ peptides/LDL, was removed with $<20 \%$ remaining at 30 min (Fig. 7). $24 \mathrm{~h}$ after injection, $<10 \%$ of the injected radioactivity was present in all animals (data not shown).

We next examined the association of the injected Ac$\mathrm{Y}(141-155)_{2} \mathrm{C} / \mathrm{LDL}$ complex with the cellular components of blood. Only $4-6 \%$ of the injected ${ }^{125}$ I-LDL of the preformed peptide/LDL complex was recovered in the cell pellet. In fact, no differences in cell association were observed for ${ }^{125} \mathrm{I}-\mathrm{LDL}$ or any peptide/25I-LDL complex, suggesting that the accelerated plasma clearance of the Ac-Y (141-155) $)_{2} \mathrm{C} /{ }^{125} \mathrm{I}-\mathrm{LDL}$, which was readily observable at $10 \mathrm{~min}$, reflected an altered tissue distribution. Preliminary studies of tissue distribution and plasma clearance demonstrated that substantial tissue uptake occurred as soon as $5 \mathrm{~min}$ after injection. Therefore, as a first approximation, 10 min was chosen to measure tissue distribution because it was long enough for the apparent distribution volume of the injected ${ }^{125}$ I-LDL to reach equilibrium (33), but short enough to circumvent degradation so that the radioactivity was representative of the injected ${ }^{125}$ I-LDL.

As expected, the organ distribution of control peptide complexes $\mathrm{Y}(141-155)_{2} /{ }^{125} \mathrm{I}-\mathrm{LDL}$ and (141-P-155) $)_{2} / 125 \mathrm{I}-\mathrm{LDL} / \mathrm{Y}$ was essentially the same as the distribution of ${ }^{125} \mathrm{I}$ - LDL alone (Fig. 8). Approximately $12 \%$ of the TCA-precipitable radioactivity was recovered in the liver. Much smaller amounts were recovered with the kidney, spleen, and heart. In contrast, within $10 \mathrm{~min}$, the liver association of Ac-Y(141-155) $\mathrm{C}_{2} /{ }^{125} \mathrm{I}-\mathrm{LDL}$ represented $33 \%$ of the injected dose, and this confirmed enhanced uptake of the Ac-Y (141-155) $)_{2} \mathrm{C}^{125} \mathrm{I}-\mathrm{LDL}$ complex by the liver. In contrast to the liver, no increased association of the Ac-Y(141-155) ${ }_{2} \mathrm{C}^{125} \mathrm{I}-\mathrm{LDL}$ complex was detected in the kidney, and only a slight increased association with the heart was observed. The contribution of the heart to uptake (per organ) compared with liver was not substantial, and was slightly more per $g$ of wet tissue (Fig. $8 \mathrm{~B}$ ). However, a high degree of association with the spleen was observed, suggesting preferential retention of the Ac-Y(141-155) ${ }_{2} \mathrm{C} /{ }^{125} \mathrm{I}-\mathrm{LDL}$ complex in the spleen as well as the liver.

Acute effects of free peptides on plasma cholesterol. To monitor the effectiveness of the peptides in clearing cholesterol in vivo, nonradioiodinated free peptides $\mathrm{Y}(141-155)_{2}$, $\mathrm{Y}(141-\mathrm{P}-155)_{2}$, and Ac-Y(141-55) $)_{2} \mathrm{C}$ were injected intravenously into mice via the tail vein. Blood was obtained before and for $120 \mathrm{~min}$ after a single injection. Apo E-deficient mice of both sexes between 2 and 3 mo of age were used, and the concentration of plasma cholesterol in these 47 chow-fed animals before injection of peptide ranged from 350 to $450 \mathrm{mg} / \mathrm{dl}$.

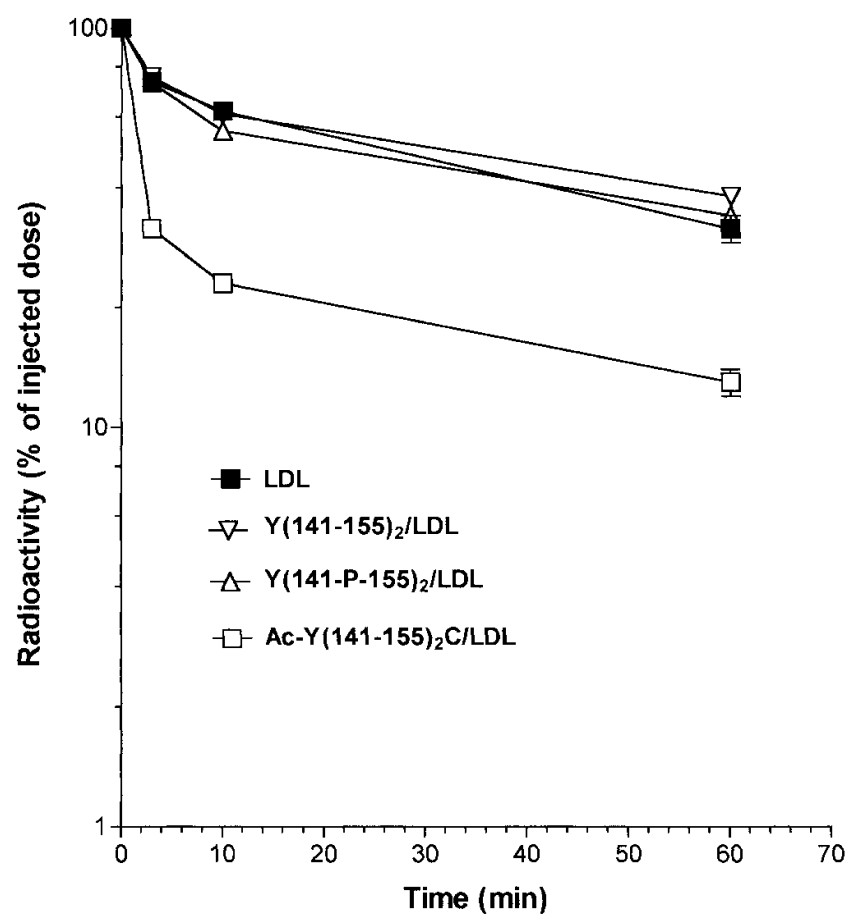

Figure 7. Effect of apoE peptides on ${ }^{125}$ I-LDL plasma clearance. Groups of apoE-deficient mice were bled at various times after intravenous administration of $0.1 \mathrm{nmol}$ of ${ }^{125} \mathrm{I}$-LDL in the absence or presence of peptides at peptide/LDL ratios shown in Table I. Data are expressed as percent of total injected TCA $(10 \%)$ precipitable radioactivity detected in plasma. Each point on the curve represents the mean \pm 1 SEM of data obtained from four animals for the 10-min time point, and from two animals for the 3-min and 1-h time points. At $24 \mathrm{~h},<10 \%$ of the injected radioactivity was found in the circulation of all 32 mice studied. 


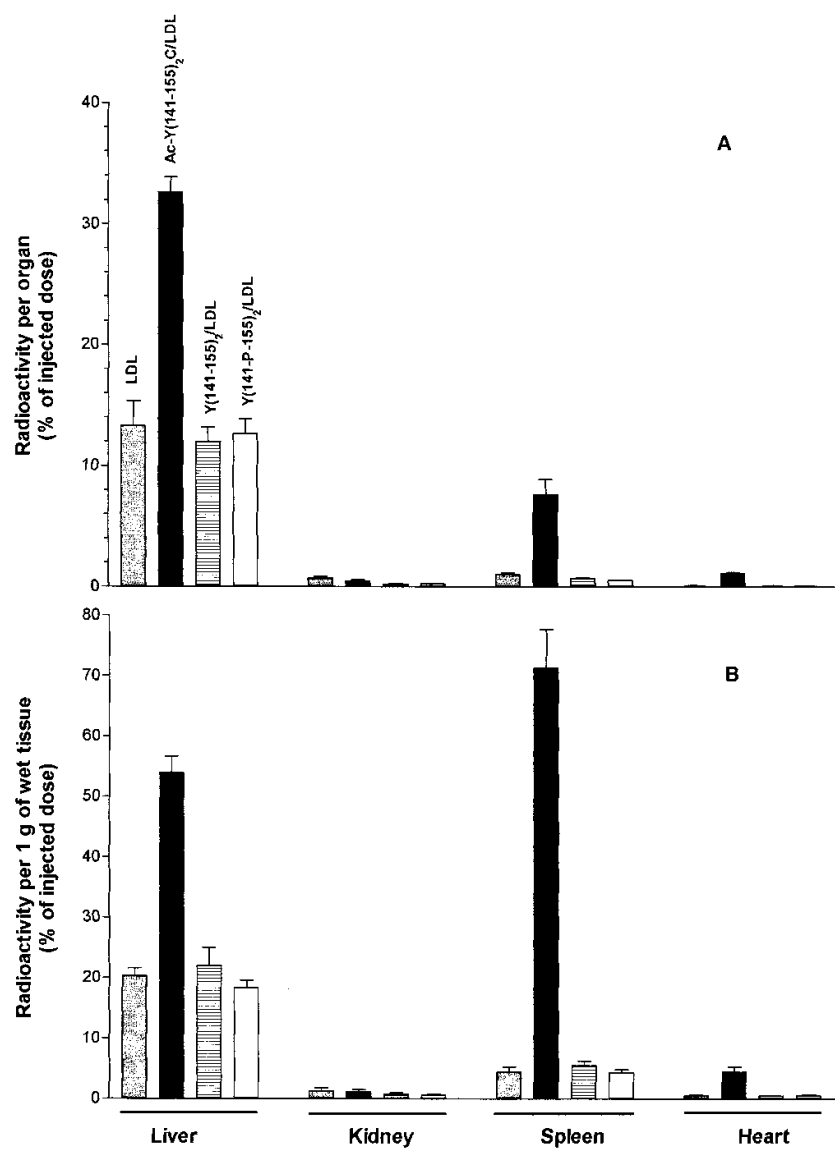

Figure 8. Association of ${ }^{125} \mathrm{I}-\mathrm{LDL}$ and peptide/ ${ }^{125} \mathrm{I}$-LDL complexes with liver, kidney, spleen, and heart. The apoE-deficient mice were killed $10 \mathrm{~min}$ after intravenous administration of $0.1 \mathrm{nmol}$ of ${ }^{125} \mathrm{I}-\mathrm{LDL}$ alone or in complex with peptides. After perfusion with cold PBS and dissection, organ-associated radioactivity was determined. Each value represents the mean \pm 1 SEM of four animals per group. $(A)$ Data are expressed as percent of injected radioactivity per organ. $(B)$ Same data expressed as percent of injected radioactivity/g of wet tissue.

Although injection of $100 \mu \mathrm{g} /$ mouse of $\mathrm{Y}(141-155)_{2}$ and $\mathrm{Y}(141-\mathrm{P}-155)_{2}$ decreased total cholesterol, the levels observed only moderately deviated from the drop observed in control animals injected with only PBS (Fig. 9). In contrast, intravenous injection of $60 \mu \mathrm{g} / \mathrm{mouse}$ of Ac-Y(141-155) $)_{2} \mathrm{C}$ resulted in a substantial (30\%) decrease of plasma cholesterol within 3-5 min. Furthermore, this Ac-Y(141-155) 2 C peptide-induced decrease in total cholesterol was maintained for the next $120 \mathrm{~min}$.

Acute effects of free peptides on plasma lipoprotein cholesterol distribution. To define the target lipoproteins of the injected free peptides, plasma cholesterol profiles of the apoEdeficient mice obtained 15 min after injection were compared with the profiles of both noninjected mice and mice injected with PBS. Pools of equal volumes of plasmas obtained from four mice with similar initial plasma cholesterol levels were prepared from each experimental control group. The major cholesterol-carrying lipoprotein classes in apoE-deficient mice are VLDL and IDL (6), and as shown in Fig. $10 \mathrm{~A}$, the cholesterol in these lipoprotein fractions at 15 min was not significantly affected by injection of PBS, $100 \mu \mathrm{g}$ of $\mathrm{Y}(141-155)_{2}$, or
$100 \mu \mathrm{g}$ of $\mathrm{Y}(141-\mathrm{P}-155)_{2}$. However, intravenous administration of $60 \mu \mathrm{g}$ of $\mathrm{Ac}-\mathrm{Y}(141-155)_{2} \mathrm{C}$ altered the lipoprotein cholesterol distribution. For this experimental group, the plasmas of individual mice were chromatographed, and the cholesterol distribution plotted in Fig. $10 \mathrm{~A}$ represents the mean of five animals. Ac-Y(141-155) ${ }_{2} \mathrm{C}$ decreased the cholesterol content of the VLDL and IDL fractions by $40-50 \%$ and $20-26 \%$, respectively. No systematic alterations of LDL and HDL cholesterol were observed. These results suggested that the Ac-Y(141155 $)_{2} \mathrm{C}$ peptide affected a selective decrease of the cholesterolrich lipoproteins. However, by monitoring only the cholesterol profile, we could not distinguish between an influence of the peptide on the cholesterol content of the VLDL and IDL and the plasma clearance of the intact lipoprotein. Therefore, the protein profiles of the plasmas were examined as well. Comparison of Fig. 10, $A$ and $B$ revealed similar changes in VLDL/ IDL cholesterol and protein, and indicated that the Ac-Y(141$155)_{2} \mathrm{C}$ peptide increased the plasma clearance of VLDL and IDL.

\section{Discussion}

ApoE mediates cellular binding of cholesterol-rich lipoproteins (1). Defective apoE-mediated cellular uptake of lipoproteins results in hyperlipidemia and premature atherosclerosis $(5,7)$. Therefore, we sought to design a synthetic peptide that could emulate the activity of intact apoE. Although the previ-

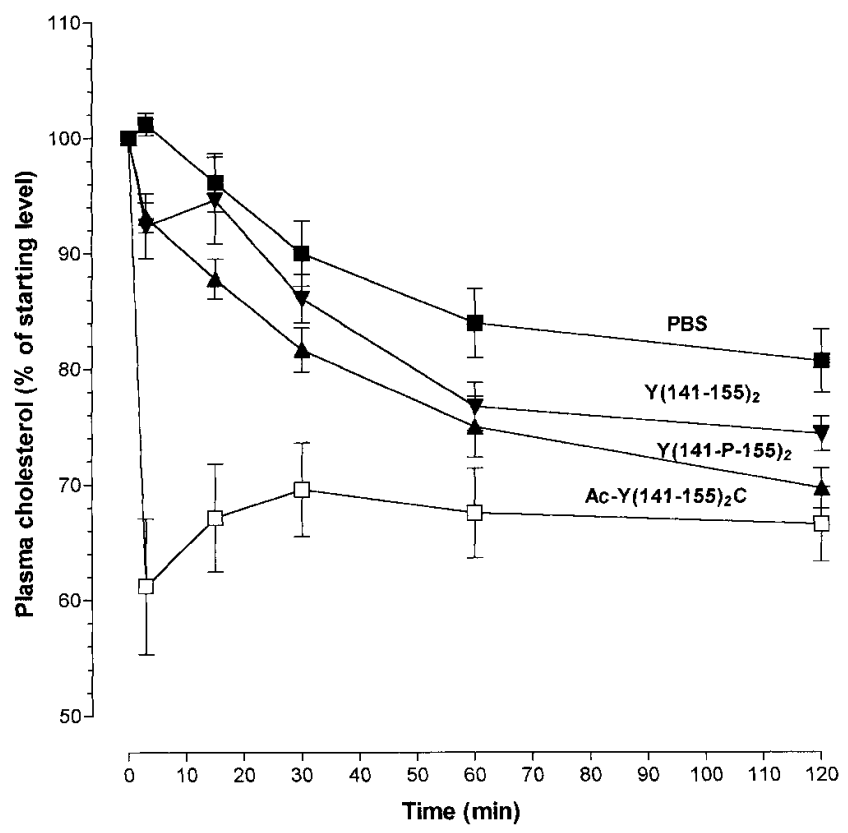

Figure 9. Influence of a single injection of peptide on plasma cholesterol in apoE-deficient mice. Free peptides were administered intravenously, and $0.02-0.03 \mathrm{ml}$ of blood was obtained at the times indicated. Data were normalized by expressing values as percent change in cholesterol after injection. Starting cholesterol levels of all animals studied ranged from 350 to $450 \mathrm{mg} / \mathrm{dl}$. Each point represents the mean $( \pm \mathrm{SD})$ of cholesterol (determined in duplicate) in plasmas obtained from the following: $\mathbf{\square}, 10$ mice injected with PBS; $\mathbf{\nabla}, 10$ mice injected with $\mathrm{Y}(141-155)_{2}(100 \mu \mathrm{g} / 15.4 \mathrm{nmol}$ per mouse $) ; \boldsymbol{\Lambda}, 11$ mice injected with $\mathrm{Y}(141-\mathrm{P}-155)_{2}(100 \mu \mathrm{g} / 15.8 \mathrm{nmol}$ per mouse $)$; and $\square, 17$ mice injected with Ac- $\mathrm{Y}(141-155)_{2} \mathrm{C}(60 \mu \mathrm{g} / 7.1 \mathrm{nmol} / \mathrm{mouse})$. 


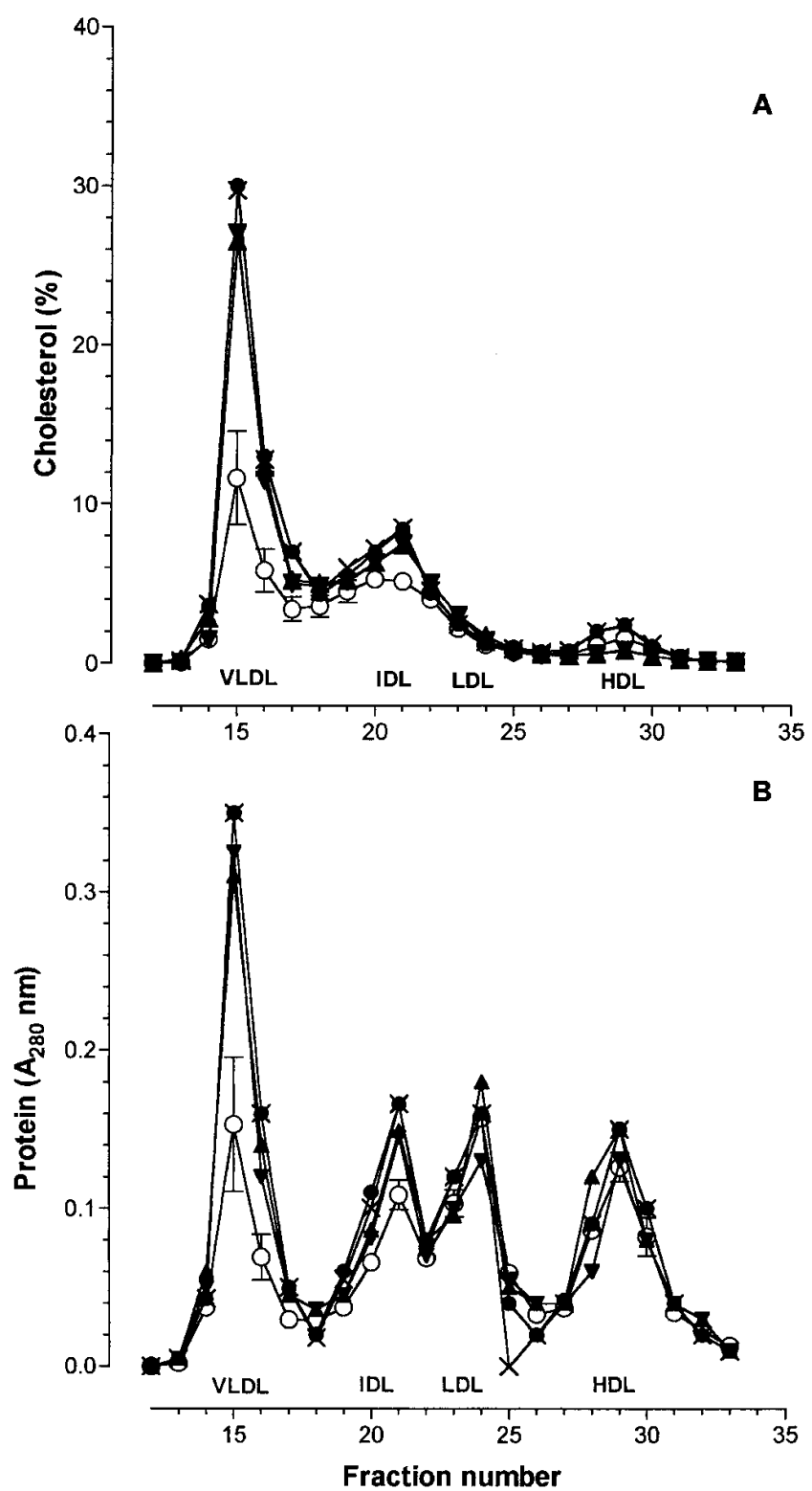

Figure 10. Acute effect of the apoE synthetic peptides on cholesterol and protein content of plasma lipoproteins of apoE-deficient mice. Peptides were administered intravenously, and blood samples were obtained before and $15 \mathrm{~min}$ after injection. Pooled plasma $(0.1 \mathrm{ml})$ from four mice in the control groups was chromatographed on a Su-

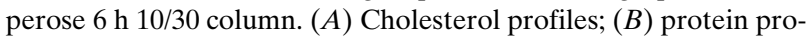
files of $0.5-\mathrm{ml}$ fractions. $\bullet$, Before injection; $\boldsymbol{\nabla}, 15 \mathrm{~min}$ after injection of PBS; $\boldsymbol{\Delta}, 15 \mathrm{~min}$ after injection of Y $(141-155)_{2}(100 \mu \mathrm{g} / 15.4 \mathrm{nmol} /$ mouse); $\square, 15 \mathrm{~min}$ after injection of Y(141-P-155) $2(100 \mu \mathrm{g} /$ $15.8 \mathrm{nmol} /$ mouse). The plasmas of the five mice who received $60 \mu \mathrm{g} /$ $\mathrm{nmol} / \mathrm{mouse}(7.1 \mathrm{nmol})$ of Ac-Y $(141-155)_{2} \mathrm{C}(\bigcirc)$ were chromatographed individually, and the data was expressed as the mean $\pm \mathrm{SD}$ of the five animals. Plasma cholesterol in each fraction is expressed as a percent of the total cholesterol applied to the column in the $0.1 \mathrm{ml}$ of plasma.

ously studied apoE dimer peptide $\mathrm{Y}(141-155)_{2}$ bound to lipoprotein receptors, had an $\alpha$-helical conformation, and was amphipathic, it had a low affinity for lipoproteins (10). To improve the lipid-binding properties of the peptide, we designed peptides with acyl chains attached to the $\mathrm{NH}_{2}$ terminal. A di- rect relationship between the number of attached $\mathrm{NH}_{2}$-terminal carbon units and the hydrophobicity of a peptide has been demonstrated. Ponsin and coworkers $(25,26)$ showed an increase in lipid-associating properties of a synthetic peptide as the $\mathrm{NH}_{2}$-terminal acyl chain was increased from 1 to 16 . Mims et al. (33) showed that attachment of the $N, N$-distearil derivative of glycine (diC18-Gly) to a 129-169 apoE peptide strongly increased its affinity for LDL.

Helical wheel diagrams of the peptides, which reflect the distribution of the polar and nonpolar amino acid residues, indicate that the $\mathrm{NH}_{2}$-terminal tyrosine of the $\mathrm{Y}(151-155)_{2}$ dimer peptide is situated close to a polar-nonpolar interface (10). Therefore, we predicted that the attachment of palmitic acid to this residue should increase the hydrophobicity of the helix. Although no dramatic changes in the calculated structure were found with the Pal-Y(141-155) $)_{2}$ computer-generated model (data not shown), its lipid affinity was dramatically increased. This high affinity for lipid makes this peptide a good tool to follow the transfer of peptides among lipoproteins according to a hydrophobicity gradient, or to trace the metabolism of peptide-containing lipoproteins in vitro. However, this peptide was inappropriate for use in vivo because of its insolubility. Although we were able to solubilize Pal-Y(141-155) $)_{2}$ by dissolving it in sodium cholate and incorporating it into liposomes containing PA and PC, this peptide was not transferred to lipoproteins in plasma. Rather, the peptide-containing liposomes fused with the lipoproteins. Furthermore, because the amount of PA needed to increase the peptide content of the liposomes was toxic for cultured cells, further cell studies were not feasible.

To define the minimal number of $\mathrm{NH}_{2}$-terminal carbon units that were necessary to increase the lipid-associating properties of the $\mathrm{Y}(141-155)_{2}$ peptide without altering its solubility, we attached acetic acid to the $\mathrm{NH}_{2}$-terminal tyrosine of the dimer peptide. Computer predictions of the influence of this $\mathrm{NH}_{2}$-terminal acetic acid (as well as a carboxyl-terminal cysteine residue) on the solvated structure of the peptide suggested that the modification had a minimal effect on the conformation of the dimer peptide. This new peptide, Ac-Y (141-155) ${ }_{2} \mathrm{C}$, had good solubility at neutral $\mathrm{pH}$, was relatively resistant to degradation when it was added to plasma at $37^{\circ} \mathrm{C}$, and had improved lipid binding properties. Furthermore, it formed stable complexes in vitro with peptide/LDL molar ratios of 4-5:1.

Because Ac-Y(141-155) $)_{2} \mathrm{C}$ targeted to lipoproteins in plasma, we tested its ability to associate with cultured cells. This peptide bound directly to fibroblasts, and it also increased the association of LDL with cells. In competition studies, the apoE-rich HDLc are more effective than LDL in competing with ${ }^{125}$ I-LDL for receptor sites (34). Innerarity et al. (35) and Pitas et al. (36) showed that when apoE is complexed with dimyristoylphosphatidylcholine, discoidal particles containing four apoE molecules are formed. Using these discoidal particles with various ratios of receptor-inactive (chemically modified) and receptor-active apoE, these authors determined that apoE binds to the LDL receptor with an affinity similar to that of LDL, but the binding of phospholipid discs containing four receptor-active molecules of apoE is substantially higher and similar to the binding of HDLc. Our data suggests that the Ac-Y(141-155) ${ }_{2}$ C/LDL complexes behaved similarly to apoEenriched LDL in vitro.

Downregulation of fibroblast LDL receptors by culture in 
lipoprotein-containing serum reduced the binding of Ac$\mathrm{Y}(141-155)_{2} \mathrm{C} /{ }^{125} \mathrm{I}-\mathrm{LDL}$ complexes by $75 \%$. Ji et al. (31) demonstrated that $\sim 90 \%$ of beta-VLDL binding to HepG2 cells is inhibited by antibody known to block the LDL receptorligand interactions, whereas only $\sim 10 \%$ of the enhanced binding displayed by beta-VLDL enriched in apoE is inhibited by this antibody. This result suggests that additional cellular sites are involved in apoE-mediated cellular associations. The interaction of apoE with LRP has been studied extensively using rabbit beta-VLDL $(12,13)$. To interact effectively with LRP, the apoE content of rabbit beta-VLDL must be enriched by incubation with exogenous apoE (13). Because LRP is constitutive and cannot be downregulated, we tested its contribution in our system by studying binding to LDL receptor-downregulated cells. At the ligand concentrations studied, $\sim 25 \%$ of the total binding was observed in LDL-R-depleted cells, suggesting that the LRP receptor could be involved as well.

Moreover, consideration was given to the possibility that cell-surface proteoglycans were involved in the enhanced association of the peptide-enriched lipoproteins. ApoE has been shown to bind heparin $(37,38)$. Ji et al. demonstrated that heparinase treatment decreased the binding of beta-VLDL enriched with apoE by $~ 80 \%$ in normal fibroblasts, and by $>90 \%$ in fibroblasts from an LDL receptor-deficient patient with familial hypercholesterolemia. Because a heparin-binding site exists between apoE residues $142-147(37,38)$ and overlaps with residues of Ac-Y (141-155) 2 , we examined the effect of removing cell HSPG on the association of the peptide/LDL complex. Pretreatment of human skin fibroblasts with heparinase removed $\sim 45 \%$ of the total proteoglycans and blocked $70 \%$ of the Ac-Y $(141-155)_{2} \mathrm{C} / 125 \mathrm{I}-\mathrm{LDL}$ binding. The binding activity that remained approached that observed for LDL without peptide. Furthermore, the binding of peptide-free ${ }^{125}$ I-LDL was not inhibited by heparinase treatment. Therefore, both HSPG and LRP-receptors probably contributed to the enhanced cellular association of peptide-enriched lipoproteins.

Plasma clearance and tissue distribution of the peptides were assessed after they were injected intravenously into chow-fed C57BL/6J apoE-deficient mice with high levels of cholesterol-rich chylomicron remnants VLDL and IDL (4-7). The tissue association and plasma clearance of ${ }^{125}$ I-LDL complexed to control peptides $\mathrm{Y}(141-155)_{2}$ or Y(141-P-155) ${ }_{2}$ were essentially the same as the distribution of ${ }^{125} \mathrm{I}-\mathrm{LDL}$ alone. In contrast, the Ac-Y(141-155) $)_{2} \mathrm{C}^{125} \mathrm{I}$-LDL peptide complex was cleared from plasma at a substantially higher rate, implying that Ac-Y(141-155) 2 C enhanced binding of the radioiodinated LDL to tissue LDL/LRP receptors and/or cell surface HSPG.

ApoE is thought to contribute to liver retention of lipoproteins by increasing their association with the cell-surface HSPG that favor receptor interactions (15). It is postulated that HSPG on the surface of hepatocytes are responsible for the initial sequestration and binding of chylomicron remnants in the space of Disse. Because HSPG binding of the Ac-Y $(141-155)_{2} \mathrm{C}$ peptide-enriched lipoproteins to cells was observed in vitro, an interaction of the peptide/lipoprotein complex to HSPG could contribute to the initial rapid (within 3 min) clearance of the lipoproteins from the plasma we observed in this study. Furthermore, these results are consistent with the two-receptor model of hepatic clearance, which is observed with lipoproteins that contain intact apoE (39).

The increased uptake of the Ac-Y(141-155) $)_{2} \mathrm{C} /{ }^{125} \mathrm{I}-\mathrm{LDL}$ peptide complex by the spleen was probably due to macrophage-mediated uptake. Macrophages express both LDL and LRP receptors $(1,12)$. Furthermore, Ac-Y(141-155) 2 C may have favored receptor interaction by HSPG on the surface of macrophages (14). Macrophages also express a VLDL receptor (belonging to the LRP-receptor family) that does not interact with lipoproteins containing only apoB (40). Thus, the peptide/LDL complex could have been cleared by this pathway as well. Together, studies of the in vivo fate of a single injection of $7 \mathrm{nmol}$ of an Ac-Y(141-155) 2 C/LDL complex indicated that the complex was cleared rapidly from plasma and could be found in the liver.

The Ac-Y(141-155) 2 C peptide facilitated enhanced liver binding and plasma clearance, data consistent with the role of apoE in vivo. ApoE enrichment of lipoproteins in vivo decreases cholesterol levels by favoring enhanced binding of chylomicron remnants to HSPG within the space of Disse and facilitating increased uptake by hepatocyte remnant lipoprotein receptors. ApoE is incorporated into lipoproteins when it is injected in vivo $(2,3)$. Likewise, a single intravenous injection of free Ac-Y(141-155) $)_{2} \mathrm{C}$ peptide into apoE-deficient mice reduced plasma cholesterol by $25-40 \%$ within minutes, consistent with the data of Mahley et al. (2) and Yamada et al. (3) who demonstrated a $19-34 \%$ acute reduction of plasma cholesterol in Watanabe and New Zealand white rabbits after an intravenous injection of intact apoE. Interestingly, the amount of intact apoE used for intravenous administration in the rabbits was between $6-40 \mathrm{mg} / \mathrm{rabbit}(2.5-3.5 \mathrm{~kg})$. On an animal weight basis, this is equivalent to $2-7 \mathrm{nmol} / 20 \mathrm{~g}$ mouse. In the study reported here, we administered 7 nmol of Ac-Y(141$155)_{2} \mathrm{C}$ per mouse and observed a reduction (after subtraction of PBS baseline) in the range of 30-40\% (Fig. 9).

The acute decrease in plasma cholesterol facilitated by Ac$\mathrm{Y}(141-155)_{2} \mathrm{C}$ was rapid, and probably reflected targeting of the peptide to lipoproteins followed by binding to tissue HSPG. The contribution of LDL, LRP, and VLDL receptors to this acute plasma drop cannot be determined immediately, and further study of the contribution of specific lipoprotein receptors to the observed tissue distribution is warranted. It is appropriate to emphasize that binding to LDL and remnant receptors on hepatocytes must ultimately occur to accomplish a long-term reduction in the cholesterol-rich VLDL and IDL. Importantly, the tissue distribution of the peptide/LDL complexes suggested that uptake of the peptide-associated lipoproteins by the liver occurred.

As shown in Fig. 9, the level of plasma cholesterol in the PBS-injected mice rose slightly above 100\% 3-5 min after injection, and then decreased to $70 \%$ within $24 \mathrm{~h}$. It is not known why this occurred. However, Yamada et al. (3) reported that intravenous injection of Watanabe heritable hyperlipidemic rabbits with saline also led to an initial increase (slightly above $100 \%$ ) and then a slight decrease of plasma cholesterol to 90 $95 \% 24 \mathrm{~h}$ after injection. Mahley et al. (2) observed a 6-14\% decrease of cholesterol in the plasma of the New Zealand White rabbits injected with saline. It can be postulated that the stress of injections, blood drawing, and anaesthesia are responsible for some of the acute changes we observed $(2,3)$.

Impaired catabolism of remnants occurs in humans with Type III hyperlipoproteinemia, and leads to a dramatic buildup of VLDL/IDL in the blood. This phenotype can arise from different genotypes, including receptor-binding defective apoE mutants or apoE deficiency. Furthermore, acute severe 
hypertriglyceridemia can be life-threatening. Here we show that intravenous injection of the Ac-Y $(141-155)_{2} \mathrm{C}$ peptide substantially decreased the VLDL and IDL cholesterol in the plasma of apoE-deficient mice. Modulation of the protein profile of the apoE-deficient mouse plasma lipoproteins correlated with cholesterol alterations and confirmed enhanced clearance of intact VLDL and IDL. Nevertheless, the substantial decrease in circulating peptide 30-60 min after injection indicated that the peptide had a high rate of clearance. Therefore, to circumvent the stress of repeated injections and to monitor long-term effects of these peptides on VLDL and IDL cholesterol, sustained in vivo release will be necessary. Future studies will require the use of controlled release systems that can deliver the peptide at a predetermined rate for a defined time period (41). Systems to deliver drugs and peptides for long time periods (days to years) with the peptide placed in a polymeric material, vesicle, or pump can provide for controlled release of active peptide so that the long-term effects of an apoE dimer peptide on VLDL and IDL cholesterol can be examined.

\section{Acknowledgments}

We gratefully acknowledge the technical assistance of Kathi Richards and David J. Bonnet, the helpful discussions of Drs. C. Dyer, J. Spangenberg, W. Boisvert, R. Smith and C. Banka, and the help of Anna $\mathrm{M}$. Meyers in preparation of the manuscript.

This work was supported by grants to L.K. Curtiss from The California Tobacco-Related Disease Research Program (3RT-0134 and 6RT-0034) and National Institutes of Health grant HL-35297.

\section{References}

1. Mahley, R.W. 1988. Apolipoprotein E: cholesterol transport protein with expanding role in cell biology. Science. 240:622-630.

2. Mahley, R.W., K.H. Weisgraber, M.M. Hussain, B. Greenman, M. Fisher, T. Vogel, and M. Gorecki. 1989. Intravenous infusion of apolipoprotein $\mathrm{E}$ accelerates clearance of plasma lipoproteins in rabbits. J. Clin. Invest. 83: 2125-2130.

3. Yamada, N., H. Shimano, H. Mokuno, S. Ishibashi, T. Gotohda, M. Kawakami, Y. Watanabe, Y. Akanuma, T. Murase, and F. Takaku. 1989. Increased clearance of plasma cholesterol after injection of apolipoprotein E into Watanabe heritable hyperlipidemic rabbits. Proc. Natl. Acad. Sci. USA. 86:665669.

4. Shimano, H., N. Yamada, M. Katsuki, K. Yamamoto, T. Gotoda, K. Harada, M. Shimada, and Y. Yazaki. 1992. Plasma lipoprotein metabolism in transgenic mice overexpressing apolipoprotein E. Eur. J. Clin. Invest. 90:20842091.

5. Zhang, S.H., R.L. Reddick, J.A. Piedrahita, and N. Maeda. 1992. Spontaneous hypercholesterolemia and arterial lesions in mice lacking apolipoprotein E. Science. 258:468-471.

6. Piedrahita, J.A., S.H. Zhang, J.R. Hagaman, P.M. Oliver, and N. Maeda. 1992. Generation of mice carrying a mutant apolipoprotein $\mathrm{E}$ gene inactivated by gene targeting in embryonic stem cells. Proc. Natl. Acad. Sci. USA. 89:44714475.

7. Plump, A.S., J.D. Smith, T. Hayek, K. Aalto-Setälä, A. Walsh, J.G. Verstuyft, E.M. Rubin, and J.L. Breslow. 1992. Severe hypercholesterolemia and atherosclerosis in apolipoprotein E-deficient mice created by homologous recombination in ES cells. Cell. 71:343-353.

8. Boisvert, W.A., J. Spangenberg, and L.K. Curtiss. 1995. Treatment of severe hypercholesterolemia apolipoprotein E-deficient mice by bone marrow transplantation. J. Clin. Invest. 96:1118-1124.

9. Dyer, C.A., and L.K. Curtiss. 1991. A synthetic peptide mimic of plasma apolipoprotein E that binds the LDL receptor. J. Biol. Chem. 266:22803-22806.

10. Dyer, C.A., D.P. Cistola, G.C. Parry, and L.K. Curtiss. 1995. Structural features of synthetic peptides of apolipoprotein $\mathrm{E}$ that bind the LDL receptor. J. Lipid Res. 36:80-88.

11. Dyer, C.A., R.S. Smith, and L.K. Curtiss. 1991. Only multimers of a synthetic peptide of human apolipoprotein E are biologically active. J. Biol. Chem. 266:15009-15015.

12. Herz, J., U. Hamann, S. Rogne, O. Myklebost, H. Gausepohl, and K.K.
Stanley. 1988. Surface location and high affinity for calcium of a 500-kd liver membrane protein closely related to the LDL-receptor suggest a physiological role as lipoprotein receptor. EMBO J. 7:4119-4127.

13. Kowal, R.C., J. Herz, J.L. Goldstein, V. Esser, and M.S. Brown. 1989. Low density lipoprotein receptor related protein mediates uptake of cholesteryl esters derived from apoprotein E-enriched lipoproteins. Proc. Natl. Acad. Sci. USA. 86: 5810-5814.

14. Mahley, R.W., Z.-S. Ji, W.J. Brecht, R.D. Miranda, and D. He. 1994 Role of heparan sulfate proteoglycans and the LDL receptor-related protein in remnant lipoprotein metabolism. Ann. NY Acad. Sci. 737:39-52.

15. Richardson, P.D., M.J. Davies, and G.V.R. Born. 1989. Influence of plaque configuration and stress distribution on fissuring of coronary atherosclerotic plaques. Lancet. 2(8669):941-944.

16. Jorgensen, W.L., J. Chandrasekhas, R.W. Impey, M.L. Klein. 1983. Comparison of simple potential functions for simulation liquid water. J. Chem. Phys. 79:926-935.

17. Curtiss, L.K., and R.S. Smith. 1988. Localization of two epitopes of apolipoprotein A-I that are exposed on human high density lipoproteins using monoclonal antibodies and synthetic peptides. J. Biol. Chem. 263:13779-13785.

18. Markwell, M.A.K., S.M. Haas, L.L. Bieber, and N.E.A. Tolbert. 1978. A modification of the Lowry procedure to simplify protein determination in membrane and lipoprotein samples. Anal. Biochem. 87:206-210.

19. Brand, K., C.L. Banka, N. Mackman, R.A. Terkeltaub, S.-T. Fan, and L.K. Curtiss. 1994. Oxidized LDL enhances lipopolysaccharide-induced tissue factor expression in human adherent monocytes. Arteriorscler. Thromb. 14: 790-797.

20. Goldstein, J.L., and M.S. Brown. 1974. Binding and degradation of low density lipoproteins by cultured human fibroblasts. J. Biol. Chem. 249:51535162 .

21. Gamble, W., M. Voughan, H.S. Kruth, and J. Avigan. 1978. Procedure for determination of free and total cholesterol in micro- or nanogram amounts suitable for studies with cultured cells. J. Lipid Res. 19:1068-1070.

22. Farndale, R.W., C.A. Sayers, and A.J. Barret. 1982. A direct spectrophotometric microassay for sulfated glycosaminoglycans in cartilage cultures. Connect. Tissue Res. 9:247-248.

23. Farndale, R.W., D.J. Buttle, and A.J. Barret. 1986. Improved quantitation and discrimination of sulphated glycosaminoglycans by use of dimethylmethylene blue. Biochim. Biophys. Acta. 883:173-177.

24. Sparrow, J.T., D.A. Sparrow, A.R. Culwell, and A.M. Gotto. 1985. Apolipoprotein E: Phospholipid binding studies with synthetic peptides containing the putative receptor binding region. Biochemistry. 24:6984-6988.

25. Ponsin, G., J.T. Sparrow, A.M. Gotto, Jr., and H.J. Pownall. 1986. In vivo interaction of synthetic acetylated apoE peptides with high density lipoprotein in rat. J. Clin. Invest. 77:559-567.

26. Ponsin, G., K. Strong, A.M. Gotto, Jr., J.T. Sparrow, and H.J. Pownall. 1984. In vitro binding of synthetic acetylated lipid-associating peptides to highdensity lipoproteins: Effect of hydrophobicity. Biochemistry. 23:5337-5342.

27. Westerlund, J.A., and K.H. Weisgraber. 1993. Discrete carboxyl-terminal segments of apolipoprotein E mediate lipoprotein association and protein oligomerization. J. Biol. Chem. 268:15745-15750.

28. Bachmair, A., D. Finley, and A. Varshavsky. 1986. In vivo half-life of a protein is a function of its amino-terminal residue. Science. 234:179-186.

29. Herz, J., J.L. Goldstein, D.K. Strickland, Y.K. Ho, and M.S. Brown. 1991. 39-kDa protein modulates binding of ligands to low density lipoprotein receptor-related protein/alpha 2-macroglobulin receptor. J. Biol. Chem. 266: 21232-21238.

30. Medh, J.D., G.L. Fry, S.L. Bowen, M.W. Pladet, D.K. Strickland, and D.A. Chappel. 1995. The 39-kDa receptor associated protein modulates lipoprotein catabolism by binding to LDL receptors. J. Biol. Chem. 270:536-540.

31. Ji, Z.-S., W.J. Brecht, R.D. Miranda, M.M. Hussain, T.L. Innerarity, and R.W. Mahley. 1993. Role of heparan sulfate proteoglycans in the binding and uptake of apolipoprotein E-enriched remnant lipoproteins by cultured cells. J. Biol. Chem. 268:10160-10167.

32. Ji, Z.-S., S. Fazio, Y.-L. Lee, and R.W. Mahley. 1994. Secretion-culture role for apolipoprotein $\mathrm{E}$ in remnant lipoprotein metabolism involving cell surface heparan sulfate proteoglycans. J. Biol. Chem. 269:2764-2772.

33. Mims., M.P., A.T. Darnule, R.W. Tovar, H.J. Pownall, D.A. Sparrow, J.T. Sparrow, D.P. Via, and L.C. Smith. 1994. A nonexchangeable apolipoprotein E peptide that mediates binding to the low density lipoprotein receptor. J. Biol. Chem. 269:20539-20547.

34. Pitas, R.F., T.L. Innerarity, K.S. Arnold, and R.W. Mahley. 1979. Rate and equilibrium constants for binding of apo-E HDLc (a cholesterol-induced lipoprotein) and low density lipoproteins to human fibroblasts; evidence for multiple receptor binding of apo-E HDLc. Proc. Natl. Acad. Sci. USA. 76:23112315.

35. Innerarity, T.L., R.E. Pitas, and R.W. Mahley. 1979. Binding of arginine-rich (E) apoprotein after recombination with phospholipid vesicles to the low density lipoprotein receptors of fibroblasts. J. Biol. Chem. 254:4186-4190.

36. Pitas, R.F., T.L. Innerarity, and R.W. Mahley. 1980. Cell surface receptor binding of phospholipid -protein complexes containing different ratios of receptor-active and -inactive E apoprotein. J. Biol. Chem. 255:5454-5460.

37. Weisgraber, K.H., S.C. Rall, Jr., R.W. Mahley, Y.L. Marcel, and J.T 
Sparrow. 1986. Human apolipoprotein E. Determination of the heparin binding sites of apolipoprotein E. J. Biol. Chem. 261:2068-2076.

38. Cardin, A.D., N. Hirose, D.T. Blankenship, R.L. Jackson, J.A. Harmony, D.A. Sparrow, and J.T. Sparrow. 1986. Binding of a high reactive heparin to human apolipoprotein E: identification of two heparin-binding domains. Biochem. Biophys. Res. Commun. 134:783-789.

39. Ishibashi, S., J. Herz, N. Maeda, J.L. Goldstein, and M.S. Brown. 1994. The two-receptor model of lipoprotein clearance: Tests of the hypothesis in "knockout" mice lacking the low density lipoprotein receptor, apolipoprotein E, or both proteins. Proc. Natl. Acad. Sci. USA. 91:4431-4435.

40. Takahashi, S., Y. Kawarabayasi, T. Nakai, J. Sakai, and T. Yamamoto. 1992. Rabbit very low density lipoprotein receptor: A low density lipoprotein receptor-like protein with distinct ligand specificity. Proc. Natl. Acad. Sci. USA. 89:9252-9256.

41. Langer, R. 1990. New methods of drug delivery. Science. 249:1527-1533. 